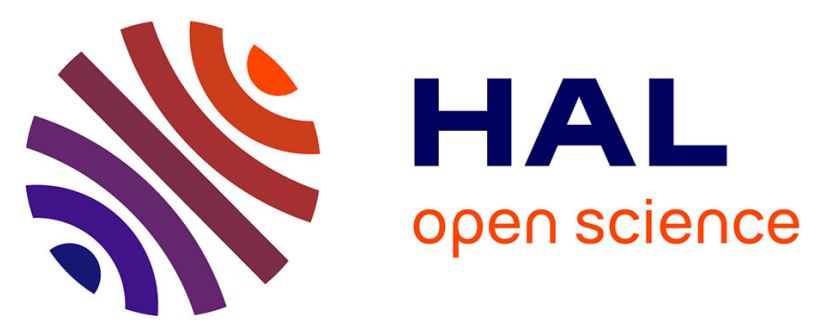

\title{
Speciation of organic fraction does matter for source apportionment. Part 1: A one-year campaign in Grenoble (France)
}

\author{
Deepchandra Srivastava, Sophie Tomaz, Olivier Favez, Grazia-Maria \\ Lanzafame, Benjamin Golly, Jean-Luc Besombes, Laurent Alleman, Jean-Luc \\ Jaffrezo, Véronique Jacob, Emilie Perraudin, et al.
}

\section{To cite this version:}

Deepchandra Srivastava, Sophie Tomaz, Olivier Favez, Grazia-Maria Lanzafame, Benjamin Golly, et al.. Speciation of organic fraction does matter for source apportionment. Part 1: A oneyear campaign in Grenoble (France). Science of the Total Environment, 2018, 624, pp.1598-1611. 10.1016/j.scitotenv.2017.12.135 . ineris-01853324

\section{HAL Id: ineris-01853324}

https://hal-ineris.archives-ouvertes.fr/ineris-01853324

Submitted on 25 Sep 2018

HAL is a multi-disciplinary open access archive for the deposit and dissemination of scientific research documents, whether they are published or not. The documents may come from teaching and research institutions in France or abroad, or from public or private research centers.
L'archive ouverte pluridisciplinaire HAL, est destinée au dépôt et à la diffusion de documents scientifiques de niveau recherche, publiés ou non, émanant des établissements d'enseignement et de recherche français ou étrangers, des laboratoires publics ou privés. 


\section{Speciation of organic fraction does matter for source apportionment. Part 1: a one-year campaign in Grenoble (France).}

D. Srivastava ${ }^{1,2,3}$, S. Tomaz ${ }^{1,2,3}$, O. Favez ${ }^{1, *}$, G. M. Lanzafame ${ }^{1}$, B. Golly ${ }^{4,6}$, J.-L. Besombes ${ }^{4}$, L. Y. Alleman ${ }^{5}$, J.-L. Jaffrezo ${ }^{6}$, V. Jacob ${ }^{6}$, E. Perraudin ${ }^{2,3}$, E. Villenave ${ }^{2,3}$, A. Albinet ${ }^{1, *}$

${ }^{1}$ INERIS, Parc Technologique Alata, BP 2, 60550 Verneuil-en-Halatte, France

${ }^{2}$ CNRS, EPOC, UMR 5805 CNRS, 33405 Talence, France

${ }^{3}$ Université de Bordeaux, EPOC, UMR 5805 CNRS, 33405 Talence, France

${ }^{4}$ Univ. Savoie Mont Blanc, LCME, 73000 Chambéry, France

${ }^{5}$ IMT Lille Douai, SAGE, 59000 Lille, France

${ }^{6}$ Univ. Grenoble Alpes, CNRS, IRD, IGE, F-38000 Grenoble, France

*Correspondence to: alexandre.albinet@ineris.fr; olivier.favez@ineris.fr

Phone - +33 34455 6485; 6949

Submitted for publication in Science of the Total Environment 


\section{Abstract}

$\mathrm{PM}_{10}$ source apportionment was performed by positive matrix factorization (PMF) using specific primary and secondary organic molecular markers on samples collected over a one year period (2013) at an urban station in Grenoble (France). The results provided a 9-factor optimum solution, including sources rarely apportioned in the literature, such as two types of primary biogenic organic aerosols (fungal spores and plant debris), as well as specific biogenic and anthropogenic secondary organic aerosols (SOA). These sources were identified thanks to the use of key organic markers, namely, polyols, odd number higher alkanes, and several SOA markers related to the oxidation of isoprene, $\alpha$-pinene, toluene and polycyclic aromatic hydrocarbons (PAHs). Primary and secondary biogenic contributions together accounted for at least $68 \%$ of the total organic carbon (OC) in the summer, while anthropogenic primary and secondary sources represented at least $71 \%$ of OC during wintertime. A very significant contribution of anthropogenic SOA was estimated in the winter during an intense $\mathrm{PM}$ pollution event $\left(\mathrm{PM}_{10}>50 \mu \mathrm{g} \mathrm{m}^{-3}\right.$ for several days; $18 \%$ of $\mathrm{PM}_{10}$ and $42 \%$ of OC). Specific meteorological conditions with a stagnation of pollutants over 10 days and possibly Fenton-like chemistry and self-amplification cycle of SOA formation could explain such high anthropogenic SOA concentrations during this period. Finally, PMF outputs were also used to investigate the origins of humic-like substances (HuLiS), which represented $16 \%$ of $\mathrm{OC}$ on an annual average basis. The results indicated that HuLiS were mainly associated with biomass burning (22\%), secondary inorganic (22\%), mineral dust (15\%) and biogenic SOA (14\%) factors. This study is probably the first to state that HuLiS are significantly associated with mineral dust.

Keywords: Aerosol, Source apportionment, Primary biogenic organics, SOA, Molecular markers, HuLiS. 


\section{Introduction}

Airborne particles (particulate matter, PM) are a major concern of current research in atmospheric science due to their impact on both climate (Boucher et al., 2013) and air quality (Heal et al., 2012). Elucidating their emission sources and transformation processes constitutes a crucial step for the elaboration of efficient and cost-effective abatement strategies.

Organic matter $(\mathrm{OM})$ is a major PM component. Organic aerosols (OA) are categorized into either primary organic aerosol (POA), directly emitted from anthropogenic and natural sources, or secondary organic aerosol (SOA), formed in the atmosphere notably via gasparticle conversion processes such as nucleation, condensation and heterogeneous multiphase chemical reactions involving (semi-) volatile compounds (VOCs or SVOCs) (Carlton et al., 2009; Ziemann and Atkinson, 2012). Due to the multiplicity of sources and of transformation mechanisms, the apportionment of the relative contribution of each of the different primary and secondary OA fractions is still fairly uncertain.

Specific organic compounds can provide insight into OA sources (Schauer et al., 1996). They are commonly referred to as molecular markers (tracers), such as levoglucosan for biomass burning (Simoneit et al., 1999a) or $\alpha$-methylglyceric acid for SOA from isoprene oxidation (Carlton et al., 2009). Source-receptor models, such as positive matrix factorization (PMF), have been widely implemented using traditional aerosol chemical speciation, such as elemental carbon (EC), organic carbon (OC), major ions, and metals. The inclusion of a comprehensive set of organic molecular markers potentially offers a closer link between factors and sources, but it has been rarely applied in PMF studies because it requires large datasets and intensive lab-work (Jaeckels et al., 2007; Laing et al., 2015; Schembari et al., 2014; Shrivastava et al., 2007; Srimuruganandam and Shiva Nagendra, 2012; Waked et al., 2014; Wang et al., 2012; Zhang et al., 2009). 
Source apportionment studies based on the use of source-receptor models assume that organic molecular markers are chemically stable in the atmosphere (defined as tracer compounds) (Schauer et al., 1996). However, these compounds can react in the atmosphere by photochemical processes involving sunlight and atmospheric oxidants such as $\mathrm{O}_{3}, \mathrm{NO}_{\mathrm{x}}$, radicals $\mathrm{OH}, \mathrm{NO}_{3} \ldots$ For instance, levoglucosan is usually assumed to be very stable (Simoneit et al., 1999b) but recent studied have shown its significant atmospheric chemical degradation (Hennigan et al., 2010; Kessler et al., 2010; Mochida et al., 2010; Zhao et al., 2014). For most of these compounds, experimental data about their stability or atmospheric lifetimes are very scarce or not available. They are usually based on empirical calculations like for SOA markers (Nozière et al., 2015). If some markers have tendency to undergo a rapid decay in the atmosphere, so short lifetime, their use may cause a bias in the source apportionment results.

The main objective of this work is to apportion specific primary and secondary OA fractions using various and distinctive molecular markers in a PMF model. The present paper is based on results obtained from a year-long campaign conducted in an Alpine city, while a following paper will be dedicated to the use of a similar approach in the Paris region during a 3-week intensive sampling campaign, with a higher time resolution for filter samplings (every $4 \mathrm{~h}$ ) through an intense PM pollution event (Srivastava et al., In preparation). A focus has been put here on usually unresolved PM sources, such as primary biogenic sources and secondary sources such as biogenic SOA formed from pinene or isoprene oxidation, and anthropogenic SOA formed from the oxidation of polycyclic aromatic hydrocarbons (PAHs), toluene and phenol. In addition, this work provides insight into the sources of total OC and of humic-like substances (HuLiS), a significant fraction of OM which plays an important role in the atmosphere (Graber and Rudich, 2006) and has not been extensively explored. 


\section{Methodology}

\subsection{Sampling site}

The sampling site was located at the urban background sampling station of "Les Frênes" $\left(45^{\circ} 09^{\prime} 41^{\prime \prime} \mathrm{N}, 5^{\circ} 44^{\prime} 07^{\prime \prime} \mathrm{E}\right)$ in Grenoble (France). The city, surrounded by three mountain ranges, is considered the most densely populated area $(160,000$ inhabitants) of the French Alps (Figure S1). In addition to the urbanized area, forests, including both deciduous and coniferous species, and agriculture areas (pastures) dominate the land cover around Grenoble (Figure S2). This region experiences frequent severe PM pollution events $\left(\mathrm{PM}_{10}>50 \mu \mathrm{g} \mathrm{m}^{-3}\right.$ for at least 3 consecutive days) in the winter due to the formation of thermal inversion layers that may promote pollutant accumulation. Previous studies have shown that residential heating, mainly biomass burning, accounts for a major fraction of $\mathrm{PM}_{2.5}$ in the winter (Favez et al., 2010). In addition, traffic and industrial activities contribute significantly to the observed PM concentration levels in Grenoble (Polo-Rehn et al., 2014).

\subsection{Sample collection}

$\mathrm{PM}_{10}$ samples (Tissu-quartz, Pallflex, $\varnothing=150 \mathrm{~mm}$ ) were collected every third day for one year from 01/01/2013 to 01/01/2014 using two parallel high volume samplers (DA-80, Digitel; sampling duration of $24 \mathrm{~h}$ at $30 \mathrm{~m}^{3} \mathrm{~h}^{-1}$ ). Details on the preparation and conservation of these filter samples have already been presented elsewhere (Tomaz et al., 2017; Tomaz et al., 2016) and are reported in the Supplementary Material. A total of 123 samples and 9 field blanks were collected and analysed for an extended chemical characterization following the protocols described in section 2.3.

Atmospheric concentrations of $\mathrm{PM}_{10}$ and $\mathrm{PM}_{2.5}$ (1405F TEOM-FDMS, Thermo), $\mathrm{NO}_{\mathrm{x}}(\mathrm{TEI}$ 42I, Thermo) and $\mathrm{O}_{3}$ (TEI 49I, Thermo) were monitored by the local air quality network in Grenoble (Atmo Rhône-Alpes-Auvergne) at a 15-min resolution. Together with the ROMMA 
network (Meteorological network of the Alpine massif), they also measured and provided meteorological parameters (temperature, wind direction, wind speed and relative humidity) (Figures 1 and S3). Temperature and pressure data from several locations at different altitudes were used to evaluate the duration of thermal inversion layers in the valley. Details of the calculation of thermal inversion layers have been described previously (Tomaz et al., 2017).

\subsection{Analytical procedures}

Overall, approximately 194 species were quantified in each sample. EC/OC was measured using a Sunset lab analyser using the EUSAAR-2 thermal protocol (Cavalli et al., 2010). HuLiS were analysed following the protocol described by Baduel et al. (2010). Anions $\left(\mathrm{Cl}^{-}\right.$, $\left.\mathrm{NO}_{3}{ }^{-}, \mathrm{SO}_{4}{ }^{2-}\right)$, cations $\left(\mathrm{NH}_{4}{ }^{+}, \mathrm{Ca}^{2+}, \mathrm{Na}^{+}, \mathrm{Mg}^{2+}, \mathrm{K}^{+}\right)$, methanesulfonic acid (MSA) and oxalate $\left(\mathrm{C}_{2} \mathrm{O}_{4}{ }^{2-}\right)$ were analysed by ionic chromatography (Jaffrezo et al., 2005). Thirty-four metals and trace elements were quantified by ICP-MS (Alleman et al., 2010). Cellulose combustion markers (biomass burning) (levoglucosan, mannosan and galactosan), 3 polyols (arabitol, sorbitol and mannitol) and glucose were quantified using HPLC-PAD (Piot et al., 2012). Twenty-one PAHs, 27 oxy-PAHs, and 32 nitro-PAHs were quantified using UPLC/UVFluorescence and GC/NICI-MS (Albinet et al., 2006; Albinet et al., 2014; Albinet et al., 2013; Tomaz et al., 2016). Twenty-seven higher alkanes (C13-C39), 10 hopanes, pristane, phytane, 5 sulfur containing PAHs, 5 lignin combustion markers (vanillin, coniferaldehyde ...) (Golly et al., 2015) and 11 compounds usually recognized as SOA markers ( $\alpha$-methylglyceric acid, pinic acid, methyl-nitrocatechols...) (Nozière et al., 2015) were analysed by GC/EI-MS. Note that the quantification of all SOA markers was performed using authentic standards. Details of the analytical procedures and sample preparation for the analysis of the SOA markers are provided in the Supplementary Material (Tables S1 and S2). 


\subsection{Source apportionment methodology}

\subsubsection{Receptor modelling}

The goal of receptor models is to solve the chemical mass balance equation between the measured species concentrations and source profiles as a linear combination of factors $p$, species profile $f$ of each source, and the amount of mass $g$ contributed to each individual sample (Eq. (1)):

$$
X_{i j}=\sum_{k=1}^{p} g_{i k} f_{k j}+e_{i j}
$$

where $X_{i j}$ represents the measured data for species $j$ in sample $i$, and $e_{i j}$ represents the residual of each sample/species not fitted by the model.

PMF is a multivariate factor analysis tool that decomposes a matrix of the observed chemistry of the samples into two matrices (factor contributions $(\mathrm{G})$ and factor profiles $(\mathrm{F})$ ) that need to be ascribed to a specific source. The best model solution is obtained by minimizing the function $Q$ (Eqs. (2)):

$$
Q=\sum_{i} \sum_{j}\left(\frac{e_{i j}}{\sigma_{i j}}\right)^{2}
$$

where $\sigma_{i j}$ represents the measurement uncertainty of each data point.

In this work, we used the U.S. Environmental Protection Agency (US-EPA) PMF 5.0 software to perform the source apportionment.

\subsubsection{Uncertainty calculations}

The estimation of uncertainties for the filter-based measurements was calculated using Eqs. (3) (Polissar et al., 1998):

$$
\sigma_{i j}=\left\{\begin{array}{lr}
\frac{5}{6} L D_{j} & \text { if } X_{i j}<L D_{j} \\
\sqrt{\left(L D_{j}\right)^{2}+\left(C V_{j} X_{i j}\right)^{2}+\left(a X_{i j}\right)^{2}} & \text { if } X_{i j} \geq L D_{j}
\end{array}\right.
$$


where $L D_{j}$ is the detection limit for compound $j$ (defined as the lowest concentrations of the compound that can be measured with a signal to noise ratio of 3$), C V_{j}$ is the coefficient of variation for compound $j$ (calculated as the standard deviation of repeated analyses divided by the mean value of the repeated analyses), and $a$ is a factor (0.03) applied to account for additional sources of uncertainty (Gianini et al., 2012). Missing concentration values were replaced by the geometric mean of the concentrations of compound $j$, and their accompanying uncertainties were set at 4 times this value.

\subsubsection{Criteria for the selection of species}

Inclusion or exclusion of a chemical species in the PMF matrix is usually based on the signal to noise ratio (S/N) (Paatero and Hopke, 2003). S/N ratios for all the quantified species in this study are given in Table S3. Species with an S/N ratio below 0.2 were automatically excluded. Additional criteria for the final selection of the input species in the PMF have been applied; compounds that are analytically difficult to quantify, i.e., with a large number of data points below the detection limit ( $>60 \%$ of total data points), those mainly associated with the gas phase (e.g., pinonic acid, low molecular weight PAHs, oxy and nitro-PAHs) (Albinet et al., 2007; Albinet et al., 2008; Isaacman-VanWertz et al., 2016; Tomaz et al., 2016), and those that are not specific markers of a given source or those with no observed temporal trends (single events or spikes, e.g., pinic acid) were excluded.

In addition, to limit the input data matrix according to the total number of samples ( $\mathrm{n}=$ 123), some species were also not included if they belonged to a single source and were well correlated with another marker of this source (e.g., cellulose combustion: levoglucosan, mannosan, galactosan $(r=0.97-0.99, \mathrm{n}=123, \mathrm{p}<0.05)$; fungal spores: arabitol, sorbitol, glucose, mannitol $(r=0.85-0.92, \mathrm{n}=123, \mathrm{p}<0.05))$. In this case, only one or two representative species were kept for the input matrix. Some other specific organic compounds, such as oxalate, MSA and methyl-nitrocatechols, were also discarded due to poor predictions by the preliminary 
model runs. Finally, a total of 47 species were used in the model (Table S4). Details about the species in the final input and the exclusion of the former ones are reported in the Supplementary Material and Table S4. $\mathrm{PM}_{10}$ concentrations were included as the total variable in the model to directly determine the source contributions to the daily mass concentrations. The total variable was defined as weak (low weight) in the model to not have influence on the solution obtained.

\subsubsection{Applied constraints}

Several constraints were applied to the base run to obtain clearer chemical source profiles in the final solution. To limit the change in the Q-value, only "soft pulling" constraints were applied. Change in the Q-robust was finally approximately 7\%. Details related to the constraints applied to each factor profile are given in Table S5.

\subsubsection{Optimization of the final solution}

The selection of the final solution was made based on three criteria, including the bootstrap results to evaluate its stability, the comparison between observed and predicted concentrations, and the evaluation of the sensitivity to the applied constraints. A mapping of over $80 \%$ of the factors for the bootstrap was taken as the threshold to indicate that the chosen solution may be appropriate. Species showing poor correlations $(r<0.5)$ between observed and modelled concentrations were evaluated carefully to determine whether they should be downweighted or excluded. A few species were finally kept despite their low correlation coefficients due to their significant role in the interpretation of selected factors (Table S6). Student's t-test was used to evaluate the effectiveness of applied constraints on the base model run and to verify whether the differences were statistically insignificant for all source profiles (two-tailed paired t-test significance test at $\mathrm{p}<0.05$ probability). 


\section{Results and discussions}

\subsection{Overview of the $\mathrm{PM}_{10}$ concentrations and pollution events}

The daily $\mathrm{PM}_{10}$ mass concentrations ranged from 2 to $83 \mu \mathrm{g} \mathrm{m}^{-3}$, with an annual average of approximately $24 \mu \mathrm{g} \mathrm{m}^{-3}$ (Figure 1). Two severe PM pollution events, which also affected the rest of France (Favez, 2013), were observed in early spring (02/25-04/08/2013) and winter (12/09-12/19/2013). A large contribution of OM and the presence of thermal inversion layers were observed during the first part of the spring PM pollution events, while the second part was influenced by long range transport and characterized by a large contribution of inorganic species, such as ammonium nitrate and sulfate. The winter pollution episode was associated with the occurrence of thermal inversion layers over a period of 10 consecutive days (Tomaz et al., 2017), where OM was the major contributor to the total $\mathrm{PM}_{10}$ loadings (Figure 1). During this winter pollution event, air quality was expected to be mainly influenced by local combustion sources, such as residential heating, notably wood combustion, and traffic, as shown by the high concentrations of primary species such as levoglucosan, NO, and PAHs (Tomaz et al., 2017; Tomaz et al., 2016).

\subsection{PM10 source apportionment}

A nine-factor output provides the most reasonable solution for this $\mathrm{PM}_{10}$ source apportionment in the Grenoble valley (Figure 2). It includes traditional aerosol sources, such as primary traffic, biomass burning, mineral dust, secondary inorganics and aged sea salt, and uncommonly resolved ones, such as primary biogenic organic aerosols (fungal spores and plant debris), as well as specific biogenic and anthropogenic SOA, all identified by the chosen molecular organic markers analysed in the $\mathrm{PM}_{10}$ fraction. The selection of factors was based on the variability explained by the $\mathrm{Q} / \mathrm{Q}_{\exp }$ ratio, the chemical interpretation of the obtained factors and the total reconstructed mass. Forcing PMF to explain the variability with a less 
number of factors $(<8)$ resulted in high $Q$ value (Figure $\mathrm{S} 4$ ), thus only solutions with eight factors and more were checked. The solutions with eight sources were less explanatory, and some factors were merged (Figure S5 and S6). Conversely, an increase in the number of sources led to the split of meaningful source profiles into two unrealistic ones (Figure S7 and S8). In the final solution, the comparison of the reconstructed $\mathrm{PM}_{10}$ contributions from all sources with measured $\mathrm{PM}_{10}$ concentrations showed very good mass closure $(r=0.93, \mathrm{n}=123$, $\mathrm{p}<0.05$ ) (Figure 2 and Table S6). Note that results from the chemical characterization of the last 2 days of the year were not validated and were excluded from the PMF matrix. In addition, most of the species showed good agreement with the measured concentrations. Few of them were poorly reconstructed by the PMF (e.g., Sb, hopanes, DHOPA (2,3-Dihydroxy-4oxopentanoic acid) and phthalic acid $(r<0.34)$ ). Low correlation coefficients were due to some single events that occurred during the year and were not well reproduced by the model. Bootstrapping on the final solution showed stable results with $\geq 84$ out of 100 bootstrap mapped factors (Table S7). Finally, no significant difference ( $>>0.05)$ was observed in the source chemical profiles between the base and the constrained runs (Table S8, Figures S9 and S10).

Overall, mineral dust (21\%) and biomass burning (20\%) sources were the main contributors to the total $\mathrm{PM}_{10}$ mass on an annual scale. Primary traffic emissions, secondary inorganic aerosols, plant debris and biogenic SOA also presented significant contributions (11 to $14 \%$ ). Aged sea salt, fungal spores and anthropogenic SOA contributed to approximately 2 to $5 \%$ of total $\mathrm{PM}_{10}$ (Figure 2). Identified aerosol sources, chemical profiles and temporal evolutions are shown in Figures 3 and 4 and discussed individually below.

\subsubsection{Secondary inorganics}

The secondary inorganics source factor (nitrate-rich) was characterized by high contributions of $\mathrm{NO}_{3}{ }^{-}$and $\mathrm{NH}_{4}{ }^{+}(69 \%$ and $63 \%$ of these species being attributed to this factor, 
respectively), with an annual average concentration of $2.9 \mu \mathrm{g} \mathrm{m} \mathrm{m}^{-3}$ and accounted for approximately $13 \%$ of $\mathrm{PM}_{10}$ mass on an annual scale (Figures 2 and 3 ). $\mathrm{Cl}^{-}$and $\mathrm{SO}_{4}{ }^{2-}$ also contributed to this source factor by approximately $30-35 \%$. The source showed large seasonal variations with very high concentrations and PM contributions during both severe PM pollution events in the early spring and, to a lesser extent, in the winter (Figure 3). In the early spring, the high $\mathrm{PM}_{10}$ concentration levels, concomitant to the high contributions of ammonium nitrate, were related to secondary formation processes, long range transport of aged air masses and direct emissions from biomass burning (Tomaz et al., 2017). On average, the sources of secondary inorganics accounted for approximately $47 \%$ of the $\mathrm{PM}_{10}$ mass during this spring pollution event. Conversely, during the December PM pollution event, this factor accounted for only approximately $1 \%$ of the total $\mathrm{PM}_{10}$ mass.

\subsubsection{Primary traffic (exhaust and non-exhaust)}

The PMF model always grouped the four hopanes (HP5 to HP8, 46\% to 69\% of the total mass of each compound) together with a significant amount of EC (48\% of its total mass) into one factor (Figure 3). These species are typical of traffic exhaust emissions and this factor was significantly correlated with $\mathrm{NO}_{\mathrm{x}}(\mathrm{r}=0.6, \mathrm{n}=123, \mathrm{p}<0.05)$. As expected and following the applied constraints, this factor showed high contributions of several metals, such as $\mathrm{Ba}(72 \%)$, $\mathrm{Cu}(69 \%), \mathrm{Sb}(70 \%), \mathrm{Pb}(64 \%)$ and $\mathrm{Fe}(50 \%)$, known as additional good indicators of road traffic emissions (Pant and Harrison, 2012; Srivastava et al., 2016; Sternbeck et al., 2002). In particular, $\mathrm{Ba}$ and $\mathrm{Sb}$ are known as specific markers of vehicular brake abrasion (Johansson et al., 2009), showing that this factor accounted for both exhaust and non-exhaust traffic emissions. Regarding OC/EC (0.9) and $\mathrm{PM}_{10} / \mathrm{EC}$ (4.3) ratios in the factor profile, their values obtained here are in good agreement with the literature data reported for primary traffic emissions (El Haddad et al., 2009; Fine et al., 2002). Interestingly, only $20 \%$ of 1-nitropyrene (1-NP), expected to be a marker of diesel emissions (Keyte et al., 2016), was associated with 
this factor. Despite several efforts, PMF was unable to increase the 1-NP contribution into this factor and it remained distributed in the biomass burning factor due its strong correlation with levoglucosan. The mixing of sources on $24 \mathrm{~h}$ filter samples, together with the specific geomorphology of Grenoble as well the atmospheric dynamic could explain such observed correlations.

Primary traffic sources accounted for $14 \%$ of the $\mathrm{PM}_{10}$ mass on a yearly average (Figure 2 ), corresponding to an annual mean concentration of $3.0 \mu \mathrm{g} \mathrm{m}^{-3}$. These values are in the range of those commonly observed at other urban background locations in Europe (5-25\%) (Belis et al., 2013; Waked et al., 2014) and with a previous study conducted at an heavy traffic site in Grenoble (traffic exhaust $=17 \%$, traffic non-exhaust $=13 \%$, contribution to $\mathrm{PM}_{10}$ ) (Polo-Rehn et al., 2014). This source showed seasonal variations with higher concentrations in a cold period, notably due to the typical atmospheric dynamic in the valley of Grenoble. However, its contribution to $\mathrm{PM}_{10}$ was rather constant through the year, except in July-August (summer vacations) when it was slightly lower (Figure 3). The highest concentrations of this source were observed during the December PM pollution event, but no drastic change of its relative contribution to $\mathrm{PM}_{10}$ was noticed even during this episode.

\subsubsection{Aged sea salt}

Given the constraints applied, this factor showed major contributions of $\mathrm{Na}^{+}$(92\% in this factor) and $\mathrm{Mg}^{2+}$ (71\% in this factor), highlighting that this source was chiefly from sea salt particles (Figure 3). The $\mathrm{Mg}^{2+} / \mathrm{Na}^{+}$ratio (0.10) was comparable to the expected ratio found for sea water (i.e., 0.11) (Curran et al., 1998; Seinfeld and Pandis, 2012) and similar to the values found at the same site in a previous study (Polo-Rehn et al., 2014). The low $\mathrm{Cl}^{-}$content (27\%) resulted in ageing processes, including well-known heterogeneous reactions between airborne sea-salt| particles and acidic pollutants (e.g., nitric and sulfuric acid) leading to the volatilization of $\mathrm{HCl}$ (Seinfeld and Pandis, 2012). This source was rather constant throughout 
the year, with a very low annual contribution (2\%) to the $\mathrm{PM}_{10}$ mass (Figure 2) and a yearly average concentration of $0.5 \mu \mathrm{g} \mathrm{m}^{-3}$, which was in agreement with the sampling site location relatively far from the Atlantic and Mediterranean coasts ( 200-500 km).

\subsubsection{Mineral dust}

This factor showed a relatively high content of mineral elements such as $\mathrm{Ti}$ (53\% in this factor), $\mathrm{Ca}$ (49\% in this factor), and $\mathrm{Al}$ (54\% in this factor), commonly originating from soils and road dust (Andersen et al., 2007; Mossetti et al., 2005; Querol et al., 2004a; Yin et al., 2005) (Figure 3). This was one of the major PM sources, corresponding to an average of 4.7 $\mu \mathrm{g} \mathrm{m}^{-3}$ and accounting for $21 \%$ of the $\mathrm{PM}_{10}$ mass on an annual average (Figure 2). It showed a typical seasonal evolution with high concentrations and contributions in the summer (dry season). Significant amounts of OM (including HuLiS) and sulfate were also observed in the chemical profile of this source, in agreement with the presence of these species in soils, within resuspended particles, and/or as condensation products onto crustal material (Falkovich et al., 2004; Kögel-Knabner, 2000).

\subsubsection{Biomass burning}

The source of the biomass burning factor was characterized by very high loadings of levoglucosan (levo), coniferaldehyde (conyferald.), and vanillic acid. This factor also showed significant contributions of PAHs (B[a]P, B [ghi]P, In[1,2,3-cd]P and Cor). It followed typical seasonal variations, with a largely higher contribution in winter (Figure 4). This source accounted for $20 \%$ of the $\mathrm{PM}_{10}$ mass on a yearly average $\left(4.5 \mu \mathrm{g} \mathrm{m}^{-3}\right.$ ) (Figure 2), with maximum contributions in winter of approximately $39 \%$. These results were in very good agreement with previous observations reported in Europe (Herich et al., 2014; Viana et al., 2015) and at the same site in the winter by Favez et al., (2010). Approximately 22-25\% of OC and $\mathrm{HuLiS}$ were associated with this factor on an annual average. Both species showed strong 
correlations with levoglucosan, especially during the cold period $(\mathrm{r}=0.85$ and $0.71, \mathrm{n}=91$, $\mathrm{p}<0.05$, i.e., late autumn and winter months). These results highlighted that biomass burning is a significant source of HuLiS, as already shown in previous field studies (Baduel et al., 2010; El Haddad et al., 2011; Lin et al., 2010). Finally, OC/levoglucosan and OC/EC ratios (=4.2 and 3.8, respectively) were in good agreement with those generally reported for aerosols from biomass burning (El Haddad et al., 2009; Favez et al., 2010; Fine et al., 2002; Gianini et al., 2013).

The biomass burning factor also included significant contributions from phthalic acid $(58 \%)$ and, to a lesser extent, from DHOPA (20\%). Both compounds are known as markers of SOA formation from the photooxidation of naphthalene and toluene, respectively (Al-Naiema and Stone, 2017; Kleindienst et al., 2004; Kleindienst et al., 2012; Kleindienst et al., 2007). In addition to vehicle exhaust, both these latter species are largely emitted by biomass burning (Baudic et al., 2016; Nalin et al., 2016; Shen et al., 2012), and previous chamber experiments have shown that SOA formation from biomass burning mainly involved the photooxidation of phenolic compounds, naphthalene, and benzene, which could together contribute up to $80 \%$ of the total observed SOA (Bruns et al., 2016). It is then expected that the factor obtained here includes both fresh and processed aerosols from biomass burning.

\subsubsection{Primary biogenics 1: plant debris}

This factor was characterized by a typical chemical fingerprint from plant waxes with significant amounts (47-82\%) of odd number higher alkanes (C27 to C31) (Rogge et al., 1993) (Figure 4). This source accounted for $11 \%$ of the $\mathrm{PM}_{10}$ mass on an annual average (2.5 $\mu \mathrm{g} \mathrm{m}^{-3}$ ) (Figure 2) and exhibited a clear seasonal pattern, with relatively higher concentrations in the warm period (May-August), in agreement with plant metabolic activity. However, concentrations were also significant for the rest of the year. PM source apportionment from plant emissions is usually not achieved in the literature. To the best of our knowledge, this is 
the first report of the identification of a plant debris source factor using higher alkanes in a PMF model (at least in Europe). A similar source has been identified in similar studies using other source apportionment models (van Drooge and Grimalt, 2015). However, as shown by the presence of elements such as $\mathrm{Ti}, \mathrm{V}, \mathrm{Al}$, and $\mathrm{Ca}$, the influence of other sources, such as resuspension from road dust and soil particles, cannot be ruled out.

\subsubsection{Primary biogenics 2: fungal spores}

This source factor was characterized by the large proportions of polyols (arabitol and sorbitol, $75-85 \%$ of the total mass of each compound in this factor) (Figure 2). These compounds have been identified in the literature as markers of primary biogenic emissions originating from primary biological aerosol particles, notably fungal spores and microbes (Bauer et al., 2008; Caseiro et al., 2009; Rogge et al., 2007; Yttri et al., 2011), and previously used to apportion primary biogenic aerosols via a PMF analysis in France (Lens) (Waked et al., 2014). This factor contributed approximately $5 \%$ of the $\mathrm{PM}_{10}$ mass on an annual average, with a concentration of $1.1 \mu \mathrm{g} \mathrm{m} \mathrm{m}^{-3}$, which was significantly lower than the contribution estimated by Waked et al. (2014) (9\% on a yearly average). This lower contribution might be explained by the fact that the present study allowed for better separation between two types of primary biogenic aerosols, as well as between primary and secondary organic aerosols.

Temporal evolution showed a clear seasonality, with maximum concentrations observed in the summer and fall seasons (from June to early November), in agreement with the higher biological activity due to higher temperatures and humidity inducing an increase in the emissions of fungal spores, fern spores and pollen grains (Graham et al., 2003; Verma et al., 2017). Maximum concentrations of arabitol and sorbitol have already been observed during the warm period in several previous studies (Bauer et al., 2008; Verma et al., 2017; Waked et al., 2014; Yttri et al., 2011). 


\subsubsection{Biogenic SOA}

The sources of the biogenic SOA factor was resolved by the use of oxidation products of isoprene ( $\alpha$-methylglyceric acid ( $\alpha$-MGA and 2-methylerythritol (2-MT)) and of $\alpha$-pinene (hydroxyglutaric acid (3-HGA)) (Carlton et al., 2009; Jaoui et al., 2008). The source factor showed very high contributions of these three SOA markers (78-90\% of the total mass of each compound). The apportionment of biogenic SOA is not commonly achieved in PMF or other models based studies (Heo et al., 2013; Hu et al., 2010; Shrivastava et al., 2007; van Drooge and Grimalt, 2015; Zhang et al., 2009). Here, the evaluation of both biogenic SOA precursors to the total biogenic SOA contribution was not possible due to the strong correlation observed between isoprene and $\alpha$-pinene SOA markers (e.g., ( $\alpha$-MGA and 2-MT vs 3 -HGA, r=0.84 and 0.86 , respectively; $\mathrm{n}=123, \mathrm{p}<0.05$ ). The source of biogenic SOA showed a significant contribution to the $\mathrm{PM}_{10}$ mass of $12 \%$ on an annual average, corresponding to a concentration of $2.6 \mu \mathrm{g} \mathrm{m}^{-3}$ (Figure 2). A clear seasonal variation with larger contributions and concentrations in the summer was observed (up to $20 \%$ of PM and $16 \mu \mathrm{g} \mathrm{m}^{-3}$ ), in agreement with the higher biogenic SOC contributions already noticed during the warmer months in related studies (Kleindienst et al., 2007; Shrivastava et al., 2007; Zhang et al., 2009) (Figure 4).

\subsubsection{Anthropogenic SOA}

The last factor was characterized by high loadings of acenaphthenequinone (86\%), $6 \mathrm{H}-$ dibenzo[b,d]pyran-6-one (88\%), 1,8-naphthalic anhydride (83\%) and DHOPA (58\%). As mentioned previously, DHOPA is considered a marker of SOA formation from toluene photooxidation (Al-Naiema and Stone, 2017; Kleindienst et al., 2004; Kleindienst et al., 2007), while the three other compounds are typically by-products of PAH oxidation (phenanthrene, acenaphthene and acenaphthylene) resulting in SOA formation (Lee and Lane, 2010; Lee et al., 2012; Perraudin et al., 2007; Tomaz et al., 2017; Zhou and Wenger, 2013a; 
Zhou and Wenger, 2013b). Thus, this factor seemed characteristic of SOA from anthropogenic sources, including combustion processes such as biomass burning and traffic. Note that the primary emission of PAH oxidation products, notably by biomass burning, cannot be ignored. However, poor correlations with levoglucosan have been observed $(\mathrm{r}<0.39, \mathrm{n}=123, \mathrm{p}<0.05)$ and confirmed that these compounds were mainly originated from secondary processes in the Grenoble valley.

Anthropogenic SOA accounted for approximately $2 \%$ of the total $\mathrm{PM}_{10}$ mass, with a concentration of $0.5 \mu \mathrm{g} \mathrm{m}^{-3}$ on an annual average (Figure 2).

The source showed higher concentrations during the winter season and especially in December during the severe PM pollution event, with a contribution to $\mathrm{PM}_{10}$ of up to $18 \%$ (Figure 4).

To the best of our knowledge, this study is probably the first report of the use of PAH derivatives (here oxy-PAHs) for the apportionment of an anthropogenic SOA (PAH SOA) source. Additional tests have been performed to investigate the validity of this factor. To do this, we excluded the December data points from the complete dataset and ran the PMF model again (Table S9). The new PMF results showed that the nine factors solution was also found to be optimum and quite stable (with bootstrap >98\%) (Table S10). The chemical and temporal profiles for all the factors were totally similar to those obtained with the entire dataset, even including this factor (Figures S11 and S12, Table S11). These results confirmed the robustness of PMF outputs, which are not perturbated by the severe winter pollution event.

The large concentration peak of the source of anthropogenic SOA observed during the December PM pollution event was also noticed for all primary pollutants, including EC, levoglucosan, hopanes, several alkanes, PAHs, 1-nitropyrene and NO, underlining the large impact of primary combustion sources during this period (Tomaz et al., 2017; Tomaz et al., 
2016). In addition, several secondary compounds from anthropogenic precursors, such as DHOPA, methyl-nitrocatechols (markers for biomass burning SOA) (linuma et al., 2010), succinic and phthalic acids (Kawamura and Ikushima, 1993; Kleindienst et al., 2012) and nitro- and oxy-PAHs, exhibited very high concentrations during this period (Figure 5).

Such an event and anthropogenic SOA concentrations could be explained by a combination of several factors. First, the meteorological conditions and the geomorphology around Grenoble promoted the formation and the occurrence of thermal inversion layers for more than 10 consecutive days (Figure 1) (Tomaz et al., 2017). Together with the low wind speed $\left(<2 \mathrm{~m} \mathrm{~s}^{-1}\right)$ (Figure S3), this led to the stagnation of polluted air masses over a long period, allowing favourable conditions for chemical reactions and intense secondary formation processes. Second and interestingly, most of the metallic species and notably the transition metals $(\mathrm{Fe}, \mathrm{Cu}, \mathrm{Cr}, \mathrm{V} \ldots$ ) showed a concentration peak during the December PM pollution event (Figure 6). Such an increase of concentrations is still not fully understood, but these redox-active metals, and especially $\mathrm{Fe}$ and $\mathrm{Cu}$, are known to be involved in the catalysis of Fenton-like reactions in which they may react with hydrogen peroxide $\left(\mathrm{H}_{2} \mathrm{O}_{2}\right)$ to generate $\mathrm{OH}$ radicals (Walling, 1975). In addition, recent studies have stated the role of a Fenton reagent ( $\mathrm{Fe}, \mathrm{Cu} / \mathrm{H}_{2} \mathrm{O}_{2}$ ) in both SOA formation and PAH oxidation (Singh and Gupta, 2016; Singh and Gupta, 2017; Singh et al., 2017). Thus, transition metals could have played a significant role in the enhancement of the chemical processes and the anthropogenic SOA formation during this period. Last, Tong et al., (2016) have recently shown that SOA decomposition may also lead to the formation of $\mathrm{OH}$ radicals. The $\mathrm{OH}$ production rate by $\mathrm{SOA}$ decomposition depends on $\mathrm{Fe}^{2+}$, SOA precursors and concentrations. Such a process seems quantitatively comparable to the Fenton reaction in most conditions and may be the main source of $\mathrm{OH}$ radicals at low concentrations of $\mathrm{H}_{2} \mathrm{O}_{2}$ and $\mathrm{Fe}^{2+}$. Then, the $\mathrm{OH}$ radicals generated would promote $\mathrm{SOA}$ chemical ageing, especially in the presence of iron, increasing auto-oxidation in the 
condensed phase and further resulting in a self-amplification cycle of SOA formation (Tong et al., 2016). All these conditions were present during the December PM pollution event to promote these processes and enhance SOA formation.

\subsection{Sources of coarse and fine aerosol fractions}

Overall, the coarse aerosol fraction $\left(\mathrm{PM}_{10}-\mathrm{PM}_{2.5}\right)$ accounted for one-third of the $\mathrm{PM}_{10}$ mass. Such a proportion is in agreement with those previously reported in many different urban environments (Masri et al., 2015; Querol et al., 2004b). Figure 7 shows the tentative reconstruction of both aerosol fractions using apportioned PM sources. Interestingly, the sum of the three source factors, namely plant debris, aged sea salt, and mineral dust, showed a significant correlation with the PM mass concentration of the coarse particle mode $(\mathrm{r}=0.71$; $\mathrm{n}=123, \mathrm{p}<0.05)$. Note that to date, no consensus has emerged to precisely decide whether the source of fungal spores belongs to the fine or the coarse aerosol fraction (Liang et al., 2013; Waked et al., 2014; Wang et al., 2011). The sum of the 5 or 6 other source factors identified $\left(\mathrm{PM}_{2.5}\right.$ vs. $\Sigma_{5}$ factors, $\left.\mathrm{r}=0.91 ; \mathrm{n}=123, \mathrm{p}<0.05\right)\left(\mathrm{PM}_{2.5}\right.$ vs. $\Sigma_{6}$ factors, $\left.\mathrm{r}=0.92 ; \mathrm{n}=123, \mathrm{p}<0.05\right)$ was in very good agreement with the fine aerosol mass fraction. These results highlighted that fine particles were associated mostly with primary carbonaceous emissions together with secondary processes, while coarse particles consisted mostly of mineral dust and organic matter.

\subsection{Organic aerosol source apportionment}

\subsubsection{Organic carbon (OC)}

OC source contributions apportioned from the present PMF analysis are presented in Figure 8. On an annual average, the major contributors to OC were biomass burning (25\%), primary traffic $(12 \%)$, mineral dust (13\%), fungal spores $(12 \%)$, secondary inorganics $(11 \%)$ and plant debris (10\%), followed by both SOA fractions (14\% in total) and aged sea salt (3\%). 
These results highlighted the large contributions of primary OA sources, namely, biomass burning, traffic and biogenic source (59\% in total on an annual average). The significant impact of biomass burning within OC was in good agreement with previous findings at Grenoble (Favez et al., 2010). As expected, elevated contributions of this source to OC were obtained during the long residential heating periods in this region $(20 \%, 20 \%$ and $43 \%$ for the spring, fall and winter seasons, respectively). In addition, the traffic contribution was in the same range as that previously reported (Favez et al., 2010). The primary biogenic fraction, consisting of fungal spores and plant debris, accounted for a considerable fraction of OC (22\%), with a typical seasonal variation along with maximum concentrations and contributions up to $40 \%$ in the summer, which was related to the increase in biological activity.

Other sources, secondary inorganics, mineral dust and aged sea salt accounted together for $27 \%$ of the total OC load on a yearly basis. The primary or secondary origin of OC for these sources are discussed hereafter. The source of secondary inorganics showed a conspicuous seasonal time trend. High contributions during the spring and winter seasons were likely associated with the PM pollution events. This source factor showed a good correlation with oxalate only in the winter $(\mathrm{r}=0.84, \mathrm{n}=31, \mathrm{p}<0.05)$ and fall $(\mathrm{r}=0.70, \mathrm{n}=30, \mathrm{p}<0.05)$, indicating the influence of secondary origins for this OA source. The source of mineral dust showed a higher contribution in the summer $(22 \%)$, similar to the time trend, followed by secondary processes. The presence of HuLiS, phthalic acid, and sulfate in this source factor suggested that a part of OC was likely to be secondary. The condensation of secondary organic species on mineral dust could occur during long range transport. In addition, mineral dust may facilitate very active redox chemistry on its surface under certain conditions (i.e., in the presence of metal oxides such as $\mathrm{TiO}_{2}, \mathrm{ZnO}$, iron oxides and their exposure to sunlight) and lead to the formation of a number of different oxidized products (Aymoz et al., 2004; George 
et al., 2015). Similarly, the OC fraction in the aged sea-salt factor may be produced via a primary or bubble-mediated production mechanism at the ocean surface (Ceburnis et al., 2008), but their ageing could be explained by exposure to secondary organic aerosols precursors during the transport of air masses (Song and Carmichael, 1999).

SOA fractions from clearly identified biogenic and anthropogenic precursor origins together accounted for $14 \%$ of OC on an annual basis and ranged from $7 \%$ to $27 \%$ depending on the season. This rather low contribution could be explained by the presence of SOA in other source factors, as discussed above. The maximum contribution was observed in the summer and is of biogenic origin. Conversely, anthropogenic SOA accounted for $15 \%$ of OC in the winter and up to $42 \%$ during the December PM pollution event.

Clear-cut anthropogenic sources (i.e., primary traffic, biomass burning and anthropogenic SOA) and biogenic sources (primary and secondary) accounted for $43 \%$ and $30 \%$ of total OC on an annual average, respectively. The remaining $27 \%$ (distributed between mineral dust, secondary inorganics and aged sea salt factors) could not be unambiguously ascribed to either anthropogenic or biogenic origins. The maximum anthropogenic OC contribution was obtained during the winter season $(>71 \%)$, notably due to the impact of residential heating and the accumulation of pollutants in the valley of Grenoble, whereas the biogenic OC contribution was greatest in the summer $(>68 \%)$.

\subsubsection{Humic Like Substances (HuLiS)}

HuLiS play an important role in the atmosphere by affecting the growth of particles (Gysel et al., 2004), cloud condensation and ice nuclei formation (Facchini et al., 1999; Wang and Knopf, 2011) due to their hygroscopic and surface-active properties. They account for a significant fraction of OM (approximately 10 to 30\%) (Feczko et al., 2007). They are probably poorly photoactive (Albinet et al., 2010) but may directly react with oxidants 
(Baduel et al., 2011). They have been found to catalytically enhance the generation of reactive oxygen species (ROS) under simulated physiological conditions and may contribute to PM health impacts (Lin and Yu, 2011). The current knowledge and understanding of the sources and formation mechanisms of HuLiS are still rather poor due to the lack of source apportionment studies of this OA component (Baduel et al., 2010).

On an annual average, HuLiS accounted for approximately $8 \%$ of OM in Grenoble (from 2 to $20 \%$ ) and among the nine sources resolved by PMF, only aged sea salt did not contribute to HuLiS mass (Figure 9). Overall, 22\%, 22\%, 15\%, and 14\% of HuLiS mass were respectively associated with biomass burning, secondary inorganics, mineral dust and biogenic SOA on an annual average. PMF outputs also indicated that a non-negligible amount of HuLiS mass was attributed to plant debris, primary biogenic and primary traffic. Each of these latter sources contributed to approximately $6-8 \%$ on annual average of total $\mathrm{HuLiS}$, with higher contributions in the summer for plant debris $(11 \%)$ and in the summer and fall for fungal spores (11-14\%). While traffic emission origins have already been assigned to HuLiS (Kuang et al., 2015), no previous study explicitly reported the contribution of primary biogenics (fungal spores + plant debris) OA to these compounds.

The contribution of biomass burning to HuLiS showed a strong seasonal trend (Figure 9). It is well known that biomass combustion processes release large quantities of aromatic species into the atmosphere (Graham et al., 2002) and represent the most likely contributor to HuLiS mass in urban areas during the cold season (Baduel et al., 2010). This was confirmed by the strong correlation observed between HuLiS and levoglucosan $(r=0.81)$ and the major contribution of this source to HuLiS in the winter (37\%).

Secondary inorganics showed high contributions to HuLiS in the spring and winter (30$38 \%$ ) and negligible input in the summer. Significant correlations were observed between $\mathrm{HuLiS}$ and secondary inorganic species in the spring (HuLiS vs. $\mathrm{NH}_{4}{ }^{+}, \mathrm{SO}_{4}{ }^{2-}, \mathrm{NO}_{3}{ }^{-}, \mathrm{r}=0.82-$ 
0.84, $\mathrm{n}=30, \mathrm{p}<0.05)$ and winter $\left(\mathrm{HuLiS}\right.$ vs. $\left.\mathrm{NH}_{4}{ }^{+}, \mathrm{SO}_{4}{ }^{2-}, \mathrm{NO}_{3}{ }^{-}, \mathrm{r}=0.68-0.76, \mathrm{n}=31, \mathrm{p}<0.05\right)$. Both chamber and field studies reported up to now have shown that heterogeneous reactions of organic compounds with sulfate aerosols lead to the formation of organosulfates (Riva et al., 2015; Surratt et al., 2008), which are a major class of compounds of the HuLiS fraction (Lin et al., 2012). Sulfate aerosols, VOCs and SVOCs (including PAHs) were abundant in the Grenoble valley during the PM pollution events and could cause enhanced HuLiS formation. In addition to organosulfates, nitrated organic compounds (organonitrates) have been reported to be constituents of HuLiS (Lin et al., 2012). Organonitrates may contribute substantially to OM, especially in Europe (Kiendler-Scharr et al., 2009), and notably could have been formed during the spring PM pollution events, as has been shown for nitro-PAHs (Tomaz et al., 2017).

The large contribution of the biogenic SOA factor to HuLiS observed in the summer (47\%) can also be explained by secondary formation processes. Indeed, aqueous-phase oxidation and heterogeneous reactions involving oxidation products of biogenic VOCs (i.e., isoprene, $\alpha-$ pinene, limonene, etc..) are known to produce HuLiS (Surratt et al., 2008). In addition, anthropogenic SOA showed a low contribution to HuLiS on an annual average (6\%) but was remarkably higher in winter (14\%), especially during the December PM pollution event, as described previously. Organosulfate formation from the gas phase oxidation of PAHs (Riva et al., 2015) and the formation of HuLiS from secondary processes in liquid phase from aromatic acid precursors during biomass burning events (Altieri et al., 2008; Baduel et al., 2010; El Haddad et al., 2011) may explain such observations.

Finally, mineral dust also contributed significantly to HuLiS, especially in the warm period (17\%-26\%), with the highest contribution in the summer, which could be explained by both primary and secondary origins. HuLiS are known to be partly emitted as a primary source from soils (Graber and Rudich, 2006). High correlations were noticed between HuLiS and 
oxalate and $\mathrm{O}_{3}(\mathrm{r}=0.60-0.70, \mathrm{n}=31, \mathrm{p}<0.05)$ in the summer (Figure $\left.\mathrm{S} 13\right)$. As discussed before, mineral dust could also play a major role in secondary redox processes under favourable atmospheric conditions (George et al., 2015), and the link between HuLiS and mineral dust could be partly related to such processes.

\section{Conclusion}

Source apportionment performed using specific primary and secondary molecular markers indicated nine major $\mathrm{PM}_{10}$ sources in Grenoble (France), including sources rarely apportioned, such as primary biogenics (fungal spores + plant debris) as well as explicit SOA factors. Major contributors to $\mathrm{PM}_{10}$ mass on an annual average were biomass burning and mineral dust ( $20 \%$ of $\mathrm{PM}_{10}$ for each of them), followed by primary traffic (14\%). A high contribution of anthropogenic SOA was also observed during an intense wintertime PM pollution event. This could be explained by the accumulation of pollutants due to specific meteorological conditions and the enhancement of SOA formation via probable Fenton-like reactions and self-amplification cycles.

PMF outputs also allowed the clear identification of the overwhelming biogenic origins of organic aerosols during the summer season ( $>68 \%$ of total OC), contrasting with the predominance of anthropogenic OC during wintertime. Moreover, a peculiar emphasis was put on the sources of HuLiS, a class of compounds that constitutes a significant fraction of organic matter and is commonly considered a proxy of low volatile oxygenated organic aerosols. The results obtained here enlightened the diversity of the primary and secondary origins of these compounds, being mainly associated with biomass burning (22\%), secondary inorganics $(22 \%)$, mineral dust $(15 \%)$, and biogenic SOA $(14 \%)$ on an annual scale in Grenoble. 
The findings presented in this paper demonstrate that the speciation of the organic aerosol fraction and the input of specific molecular markers into source-receptor model are powerful tools to evaluate the contributions of discriminated OA sources and to get a better understanding of PM origins. Future works could try to incorporate even more markers (e.g., organosulfates and organonitrates) to further discriminate the nature (e.g., biogenic vs. anthropogenic) of organic aerosols that are associated with secondary inorganics, as well as mineral dusts. The use of higher time-resolution datasets (e.g., filter sampling every $6 \mathrm{~h}$ or less) could also allow the better apportionment of the influence of various secondary formation mechanisms that present different diurnal cycles.

\section{Acknowledgements}

The authors wish to thank the French Ministry of the Environment (MTEL) and the French Ministry of Research for their financial support. This work was done as part of the LCSQA activities (French reference laboratory for air quality monitoring). The authors thank Atmo Rhône-Alpes-Auvergne for filter samplings, air quality and meteorological data, Nadine Guillaumet and Noémie Nuttens for PAH analyses, Coralie Connes and Vincent Lucaire for the EC/OC, IC, sugars, organic acids and HuLis measurements, Nathalie Bocquet and Robin Aujay-Plouzeau for sample preparation and Patrick Bodu for the graphical abstract design. The Labex OSUG@2020 (ANR-10-LABX-56) is gratefully acknowledged for the analytical equipment at IGE.

\section{References}

Al-Naiema, I.M., Stone, E.A. 2017. Evaluation of anthropogenic secondary organic aerosol tracers from aromatic hydrocarbons. Atmos. Chem. Phys. 17, 2053-2065.

Albinet, A., Leoz-Garziandia, E., Budzinski, H., Villenave, E. 2006. Simultaneous analysis of oxygenated and nitrated polycyclic aromatic hydrocarbons on standard reference 
material 1649a (urban dust) and on natural ambient air samples by gas chromatography-mass spectrometry with negative ion chemical ionisation. J. Chromatogr. A. 1121, 106-113.

Albinet, A., Leoz-Garziandia, E., Budzinski, H., Villenave, E. 2007. Polycyclic aromatic hydrocarbons (PAHs), nitrated PAHs and oxygenated PAHs in ambient air of the Marseilles area (South of France): concentrations and sources. Sci. Total Environ. 384, 280-292.

Albinet, A., Leoz-Garziandia, E., Budzinski, H., Villenave, E., Jaffrezo, J.-L. 2008. Nitrated and oxygenated derivatives of polycyclic aromatic hydrocarbons in the ambient air of two French alpine valleys: Part 1: Concentrations, sources and gas/particle partitioning. Atmos. Environ. 42, 43-54.

Albinet, A., Minero, C., Vione, D. 2010. Photochemical generation of reactive species upon irradiation of rainwater: Negligible photoactivity of dissolved organic matter. Sci. Total Environ. 408, 3367-3373.

Albinet, A., Nalin, F., Tomaz, S., Beaumont, J., Lestremau, F. 2014. A simple QuEChERSlike extraction approach for molecular chemical characterization of organic aerosols: application to nitrated and oxygenated PAH derivatives (NPAH and OPAH) quantified by GC-NICIMS. Anal. Bioanal. Chem. 406, 3131-3148.

Albinet, A., Tomaz, S., Lestremau, F. 2013. A really quick easy cheap effective rugged and safe (QuEChERS) extraction procedure for the analysis of particle-bound PAHs in ambient air and emission samples. Sci. Total Environ. 450-451, 31-8.

Alleman, L.Y., Lamaison, L., Perdrix, E., Robache, A., Galloo, J.-C. 2010. PM10 metal concentrations and source identification using positive matrix factorization and wind sectoring in a French industrial zone. Atmospheric Research. 96, 612-625.

Altieri, K., Seitzinger, S., Carlton, A., Turpin, B., Klein, G., Marshall, A. 2008. Oligomers formed through in-cloud methylglyoxal reactions: Chemical composition, properties, and mechanisms investigated by ultra-high resolution FT-ICR mass spectrometry. Atmos. Environ. 42, 1476-1490.

Andersen, Z.J., Wahlin, P., Raaschou-Nielsen, O., Scheike, T., Loft, S. 2007. Ambient particle source apportionment and daily hospital admissions among children and elderly in Copenhagen. Journal of Exposure Science and Environmental Epidemiology. 17, 625.

Aymoz, G., Jaffrezo, J.-L., Jacob, V., Colomb, A., George, C. 2004. Evolution of organic and inorganic components of aerosol during a Saharan dust episode observed in the French Alps. Atmos. Chem. Phys. 4, 2499-2512.

Baduel, C., Monge, M.E., Voisin, D., Jaffrezo, J.-L., George, C., Haddad, I.E., Marchand, N., D'anna, B. 2011. Oxidation of atmospheric humic like substances by ozone: a kinetic and structural analysis approach. Environ. Sci. Technol. 45, 5238-5244.

Baduel, C., Voisin, D., Jaffrezo, J.L. 2010. Seasonal variations of concentrations and optical properties of water soluble HULIS collected in urban environments. Atmos. Chem. Phys. 10, 4085-4095.

Baudic, A., Gros, V., Sauvage, S., Locoge, N., Sanchez, O., Sarda-Estève, R., Kalogridis, C., Petit, J.-E., Bonnaire, N., Baisnée, D. 2016. Seasonal variability and source apportionment of volatile organic compounds (VOCs) in the Paris megacity (France). Atmos. Chem. Phys. 16, 11961-11989. 
Bauer, H., Claeys, M., Vermeylen, R., Schueller, E., Weinke, G., Berger, A., Puxbaum, H. 2008. Arabitol and mannitol as tracers for the quantification of airborne fungal spores. Atmos. Environ. 42, 588-593.

Belis, C.A., Karagulian, F., Larsen, B.R., Hopke, P.K. 2013. Critical review and metaanalysis of ambient particulate matter source apportionment using receptor models in Europe. Atmos. Environ. 69, 94-108.

Boucher, O., Randall, D., Artaxo, P., Bretherton, C., Feingold, G., Forster, P., Kerminen, V.M., Kondo, Y., Liao, H., Lohmann, U. Clouds and aerosols. Climate change 2013: the physical science basis. Contribution of Working Group I to the Fifth Assessment Report of the Intergovernmental Panel on Climate Change. Cambridge University Press, 2013, pp. 571-657.

Bruns, E.A., El Haddad, I., Slowik, J.G., Kilic, D., Klein, F., Baltensperger, U., Prévôt, A.S.H. 2016. Identification of significant precursor gases of secondary organic aerosols from residential wood combustion. Scientific Reports. 6, 27881.

Carlton, A.G., Wiedinmyer, C., Kroll, J.H. 2009. A review of Secondary Organic Aerosol (SOA) formation from isoprene. Atmos. Chem. Phys. 9, 4987-5005.

Caseiro, A., Bauer, H., Schmidl, C., Pio, C.A., Puxbaum, H. 2009. Wood burning impact on PM10 in three Austrian regions. Atmos. Environ. 43, 2186-2195.

Cavalli, F., Viana, M., Yttri, K., Genberg, J., Putaud, J.-P. 2010. Toward a standardised thermal-optical protocol for measuring atmospheric organic and elemental carbon: the EUSAAR protocol. Atmospheric Measurement Techniques. 3, 79-89.

Ceburnis, D., O'Dowd, C.D., Jennings, G.S., Facchini, M.C., Emblico, L., Decesari, S., Fuzzi, S., Sakalys, J. 2008. Marine aerosol chemistry gradients: Elucidating primary and secondary processes and fluxes. Geophys. Res. Lett. 35.

Curran, M.A., Van Ommen, T.D., Morgan, V. 1998. Seasonal characteristics of the major ions in the high-accumulation Dome Summit South ice core, Law Dome, Antarctica. Annals of Glaciology. 27, 385-390.

El Haddad, I., Marchand, N., Dron, J., Temime-Roussel, B., Quivet, E., Wortham, H., Jaffrezo, J.L., Baduel, C., Voisin, D., Besombes, J.L., Gille, G. 2009. Comprehensive primary particulate organic characterization of vehicular exhaust emissions in France. Atmos. Environ. 43, 6190-6198.

El Haddad, I., Marchand, N., Temime-Roussel, B., Wortham, H., Piot, C., Besombes, J.L., Baduel, C., Voisin, D., Armengaud, A., Jaffrezo, J.L. 2011. Insights into the secondary fraction of the organic aerosol in a Mediterranean urban area: Marseille. Atmos. Chem. Phys. 11, 2059-2079.

Facchini, M.C., Fuzzi, S., Zappoli, S., Andracchio, A., Gelencsér, A., Kiss, G., Krivácsy, Z., Mészáros, E., Hansson, H.C., Alsberg, T. 1999. Partitioning of the organic aerosol component between fog droplets and interstitial air. Journal of Geophysical Research: Atmospheres. 104, 26821-26832.

Falkovich, A.H., Schkolnik, G., Ganor, E., Rudich, Y. 2004. Adsorption of organic compounds pertinent to urban environments onto mineral dust particles. Journal of Geophysical Research-Atmospheres. 109.

Favez, O. 2013. Synthèse des travaux 2013 du programme CARA. LCSQA (French language).

DRC-13-136071-14096A. https://www.lcsqa.org/rapport/2013/ineris/synthese-travaux-2013-programme-cara. 
Favez, O., El Haddad, I., Piot, C., Boréave, A., Abidi, E., Marchand, N., Jaffrezo, J.L., Besombes, J.L., Personnaz, M.B., Sciare, J., Wortham, H., George, C., D'Anna, B. 2010. Inter-comparison of source apportionment models for the estimation of wood burning aerosols during wintertime in an Alpine city (Grenoble, France). Atmos. Chem. Phys. 10, 5295-5314.

Feczko, T., Puxbaum, H., Kasper-Giebl, A., Handler, M., Limbeck, A., Gelencsér, A., Pio, C., Preunkert, S., Legrand, M. 2007. Determination of water and alkaline extractable atmospheric humic-like substances with the TU Vienna HULIS analyzer in samples from six background sites in Europe. Journal of Geophysical Research: Atmospheres. $112, \mathrm{D} 23 \mathrm{~S} 10$.

Fine, P.M., Cass, G.R., Simoneit, B.R.T. 2002. Chemical Characterization of Fine Particle Emissions from the Fireplace Combustion of Woods Grown in the Southern United States. Environ. Sci. Technol. 36, 1442-1451.

George, C., Ammann, M., D’Anna, B., Donaldson, D.J., Nizkorodov, S.A. 2015. Heterogeneous Photochemistry in the Atmosphere. Chem. Rev. 115, 4218-4258.

Gianini, M., Piot, C., Herich, H., Besombes, J.-L., Jaffrezo, J.-L., Hueglin, C. 2013. Source apportionment of PM10, organic carbon and elemental carbon at Swiss sites: An intercomparison of different approaches. Sci. Total Environ. 454, 99-108.

Gianini, M.F.D., Fischer, A., Gehrig, R., Ulrich, A., Wichser, A., Piot, C., Besombes, J.L., Hueglin, C. 2012. Comparative source apportionment of PM10 in Switzerland for 2008/2009 and 1998/1999 by Positive Matrix Factorisation. Atmos. Environ. 54, 149158.

Golly, B., Brulfert, G., Berlioux, G., Jaffrezo, J.L., Besombes, J.L. 2015. Large chemical characterisation of PM10 emitted from graphite material production: Application in source apportionment. Sci. Total Environ. 538, 634-43.

Graber, E.R., Rudich, Y. 2006. Atmospheric HULIS: How humic-like are they? A comprehensive and critical review. Atmos. Chem. Phys. 6, 729-753.

Graham, B., Guyon, P., Maenhaut, W., Taylor, P.E., Ebert, M., Matthias-Maser, S., Mayol-Bracero, O.L., Godoi, R.H., Artaxo, P., Meixner, F.X. 2003. Composition and diurnal variability of the natural Amazonian aerosol. Journal of Geophysical Research: Atmospheres. 108.

Graham, B., Mayol-Bracero, O.L., Guyon, P., Roberts, G.C., Decesari, S., Facchini, M.C., Artaxo, P., Maenhaut, W., Koll, P., Andreae, M.O. 2002. Water-soluble organic compounds in biomass burning aerosols over Amazonia - 1. Characterization by NMR and GC-MS. Journal of Geophysical Research-Atmospheres. 107.

Heal, M.R., Kumar, P., Harrison, R.M. 2012. Particles, air quality, policy and health. Chem. Soc. Rev. 41, 6606-6630.

Hennigan, C.J., Sullivan, A.P., Collett, J.L., Robinson, A.L. 2010. Levoglucosan stability in biomass burning particles exposed to hydroxyl radicals. Geophys. Res. Lett. 37, L09806.

Heo, J., Dulger, M., Olson, M.R., McGinnis, J.E., Shelton, B.R., Matsunaga, A., Sioutas, C., Schauer, J.J. 2013. Source apportionments of PM2.5 organic carbon using molecular marker Positive Matrix Factorization and comparison of results from different receptor models. Atmos. Environ. 73, 51-61. 
Herich, H., Gianini, M., Piot, C., Močnik, G., Jaffrezo, J.-L., Besombes, J.-L., Prévôt, A., Hueglin, C. 2014. Overview of the impact of wood burning emissions on carbonaceous aerosols and PM in large parts of the Alpine region. Atmos. Environ. 89, 64-75.

Hu, D., Bian, Q., Lau, A.K.H., Yu, J.Z. 2010. Source apportioning of primary and secondary organic carbon in summer PM2.5 in Hong Kong using positive matrix factorization of secondary and primary organic tracer data. Journal of Geophysical Research: Atmospheres. 115.

Iinuma, Y., Boge, O., Grafe, R., Herrmann, H. 2010. Methyl-nitrocatechols: atmospheric tracer compounds for biomass burning secondary organic aerosols. Environ. Sci. Technol. 44, 8453-9.

Isaacman-VanWertz, G., Yee, L.D., Kreisberg, N.M., Wernis, R., Moss, J.A., Hering, S.V., De Sá, S.S., Martin, S.T., Alexander, M.L., Palm, B.B. 2016. Ambient gas-particle partitioning of tracers for biogenic oxidation. Environ. Sci. Technol. 50, 9952-9962.

Jaeckels, J.M., Bae, M.-S., Schauer, J.J. 2007. Positive matrix factorization (PMF) analysis of molecular marker measurements to quantify the sources of organic aerosols. Environ. Sci. Technol. 41, 5763-5769.

Jaffrezo, J.L., Aymoz, G., Delaval, C., Cozic, J. 2005. Seasonal variations of the water soluble organic carbon mass fraction of aerosol in two valleys of the French Alps. Atmos. Chem. Phys. 5, 2809-2821.

Jaoui, M., Edney, E.O., Kleindienst, T.E., Lewandowski, M., Offenberg, J.H., Surratt, J.D., Seinfeld, J.H. 2008. Formation of secondary organic aerosol from irradiated $\alpha$ pinene/toluene/NOx mixtures and the effect of isoprene and sulfur dioxide. Journal of Geophysical Research: Atmospheres. 113, D09303.

Johansson, C., Norman, M., Burman, L. 2009. Road traffic emission factors for heavy metals. Atmos. Environ. 43, 4681-4688.

Kawamura, K., Ikushima, K. 1993. Seasonal changes in the distribution of dicarboxylic acids in the urban atmosphere. Environ. Sci. Technol. 27, 2227-2235.

Kessler, S.H., Smith, J.D., Che, D.L., Worsnop, D.R., Wilson, K.R., Kroll, J.H. 2010. Chemical Sinks of Organic Aerosol: Kinetics and Products of the Heterogeneous Oxidation of Erythritol and Levoglucosan. Environ. Sci. Technol. 44, 7005-7010.

Keyte, I.J., Albinet, A., Harrison, R.M. 2016. On-road traffic emissions of polycyclic aromatic hydrocarbons and their oxy- and nitro- derivative compounds measured in road tunnel environments. Sci. Total Environ. 566-567, 1131-1142.

Kiendler-Scharr, A., Zhang, Q., Hohaus, T., Kleist, E., Mensah, A., Mentel, T.F., Spindler, C., Uerlings, R., Tillmann, R., Wildt, J. 2009. Aerosol Mass Spectrometric Features of Biogenic SOA: Observations from a Plant Chamber and in Rural Atmospheric Environments. Environ. Sci. Technol. 43, 8166-8172.

Kleindienst, T., Conver, T., McIver, C., Edney, E. 2004. Determination of secondary organic aerosol products from the photooxidation of toluene and their implications in ambient PM2. 5. J. Atmos. Chem. 47, 79-100.

Kleindienst, T.E., Jaoui, M., Lewandowski, M., Offenberg, J.H., Docherty, K.S. 2012. The formation of SOA and chemical tracer compounds from the photooxidation of naphthalene and its methyl analogs in the presence and absence of nitrogen oxides. Atmos. Chem. Phys. 12, 8711-8726. 
Kleindienst, T.E., Jaoui, M., Lewandowski, M., Offenberg, J.H., Lewis, C.W., Bhave, P.V., Edney, E.O. 2007. Estimates of the contributions of biogenic and anthropogenic hydrocarbons to secondary organic aerosol at a southeastern US location. Atmos. Environ. 41, 8288-8300.

Kögel-Knabner, I. 2000. Analytical approaches for characterizing soil organic matter. Org. Geochem. 31, 609-625.

Kuang, B., Lin, P., Huang, X.H.H., Yu, J. 2015. Sources of humic-like substances in the Pearl River Delta, China: positive matrix factorization analysis of PM 2.5 major components and source markers. Atmos. Chem. Phys. 15, 1995-2008.

Laing, J.R., Hopke, P.K., Hopke, E.F., Husain, L., Dutkiewicz, V.A., Paatero, J., Viisanen, Y. 2015. Positive Matrix Factorization of 47 Years of Particle Measurements in Finnish Arctic. Aerosol and Air Quality Research. 15, 188-207

Lee, J., Lane, D.A. 2010. Formation of oxidized products from the reaction of gaseous phenanthrene with the $\mathrm{OH}$ radical in a reaction chamber. Atmos. Environ. 44, 24692477.

Lee, J.Y., Lane, D.A., Heo, J.B., Yi, S.-M., Kim, Y.P. 2012. Quantification and seasonal pattern of atmospheric reaction products of gas phase PAHs in PM2. 5. Atmos. Environ. 55, 17-25.

Liang, L., Engling, G., He, K., Du, Z., Cheng, Y., Duan, F. 2013. Evaluation of fungal spore characteristics in Beijing, China, based on molecular tracer measurements. Environmental Research Letters. 8, 014005.

Lin, P., Huang, X.-F., He, L.-Y., Zhen Yu, J. 2010. Abundance and size distribution of HULIS in ambient aerosols at a rural site in South China. J. Aerosol Sci. 41, 74-87.

Lin, P., Yu, J.Z. 2011. Generation of Reactive Oxygen Species Mediated by Humic-like Substances in Atmospheric Aerosols. Environ. Sci. Technol. 45, 10362-10368.

Lin, P., Yu, J.Z., Engling, G., Kalberer, M. 2012. Organosulfates in Humic-like Substance Fraction Isolated from Aerosols at Seven Locations in East Asia: A Study by UltraHigh-Resolution Mass Spectrometry. Environ. Sci. Technol. 46, 13118-13127.

Masri, S., Kang, C.M., Koutrakis, P. 2015. Composition and sources of fine and coarse particles collected during 2002-2010 in Boston, MA. J. Air Waste Manage. Assoc. 65, 287-97.

Mochida, M., Kawamura, K., Fu, P., Takemura, T. 2010. Seasonal variation of levoglucosan in aerosols over the western North Pacific and its assessment as a biomass-burning tracer. Atmos. Environ. 44, 3511-3518.

Mossetti, S., Angius, S.P., Angelino, E. 2005. Assessing the impact of particulate matter sources in the Milan urban area. Int. J. Environ. Pollut. 24, 247-259.

Nalin, F., Golly, B., Besombes, J.-L., Pelletier, C., Aujay-Plouzeau, R., Verlhac, S., Dermigny, A., Fievet, A., Karoski, N., Dubois, P. 2016. Fast oxidation processes from emission to ambient air introduction of aerosol emitted by residential log wood stoves. Atmos. Environ. 143, 15-26.

Nozière, B., Kalberer, M., Claeys, M., Allan, J., D’Anna, B., Decesari, S., Finessi, E., Glasius, M., Grgić, I., Hamilton, J.F., Hoffmann, T., Iinuma, Y., Jaoui, M., Kahnt, A., Kampf, C.J., Kourtchev, I., Maenhaut, W., Marsden, N., Saarikoski, S., SchnelleKreis, J., Surratt, J.D., Szidat, S., Szmigielski, R., Wisthaler, A. 2015. The Molecular 
Identification of Organic Compounds in the Atmosphere: State of the Art and Challenges. Chem. Rev. 115, 3919-3983.

Paatero, P., Hopke, P.K. 2003. Discarding or downweighting high-noise variables in factor analytic models. Anal. Chim. Acta. 490, 277-289.

Pant, P., Harrison, R.M. 2012. Critical review of receptor modelling for particulate matter: a case study of India. Atmos. Environ. 49, 1-12.

Perraudin, E., Budzinski, H., Villenave, E. 2007. Identification and quantification of ozonation products of anthracene and phenanthrene adsorbed on silica particles. Atmos. Environ. 41, 6005-6017.

Piot, C., Jaffrezo, J.-L., Cozic, J., Pissot, N., El Haddad, I., Marchand, N., Besombes, J.-L. 2012. Quantification of levoglucosan and its isomers by High Performance Liquid Chromatography-Electrospray Ionization tandem Mass Spectrometry and its application to atmospheric and soil samples. Atmospheric Measurement Techniques. $5,141-148$.

Polissar, A.V., Hopke, P.K., Paatero, P., Malm, W.C., Sisler, J.F. 1998. Atmospheric aerosol over Alaska: 2. Elemental composition and sources. Journal of Geophysical Research: Atmospheres 103, 19045-19057.

Polo-Rehn, L., Waked, A., Charron, A., Piot, C., Besombes, J.-L., Marchand, N., Guillaud, G., Favez, O., Jaffrezo, J.-L. 2014. Estimation de la contribution des émissions véhiculaires à l'échappement et hors échappement aux teneurs atmosphériques en PM10 par Positive Matrix Factorization (PMF). Pollution atmosphérique. 221.

Querol, X., Alastuey, A., Viana, M., Rodriguez, S., Artíñano, B., Salvador, P., Do Santos, S.G., Patier, R.F., Ruiz, C., De la Rosa, J. 2004a. Speciation and origin of PM10 and PM2. 5 in Spain. J. Aerosol Sci. 35, 1151-1172.

Querol, X., Alastuey, A., Viana, M.M., Rodriguez, S., Artiñano, B., Salvador, P., Garcia do Santos, S., Fernandez Patier, R., Ruiz, C.R., de la Rosa, J., Sanchez de la Campa, A., Menendez, M., Gil, J.I. 2004b. Speciation and origin of PM10 and PM2.5 in Spain. J. Aerosol Sci. 35, 1151-1172.

Riva, M., Tomaz, S., Cui, T., Lin, Y.H., Perraudin, E., Gold, A., Stone, E.A., Villenave, E., Surratt, J.D. 2015. Evidence for an unrecognized secondary anthropogenic source of organosulfates and sulfonates: gas-phase oxidation of polycyclic aromatic hydrocarbons in the presence of sulfate aerosol. Environ. Sci. Technol. 49, 6654-64.

Rogge, W.F., Hildemann, L.M., Mazurek, M.A., Cass, G.R., Simoneit, B.R.T. 1993. Sources of fine organic aerosol. 4. Particulate abrasion products from leaf surfaces of urban plants. Environ. Sci. Technol. 27, 2700-2711.

Rogge, W.F., Medeiros, P.M., Simoneit, B.R. 2007. Organic marker compounds in surface soils of crop fields from the San Joaquin Valley fugitive dust characterization study. Atmos. Environ. 41, 8183-8204.

Schauer, J.J., Rogge, W.F., Hildemann, L.M., Mazurek, M.A., Cass, G.R., Simoneit, B.R. 1996. Source apportionment of airborne particulate matter using organic compounds as tracers. Atmos. Environ. 30, 3837-3855.

Schembari, C., Bove, M.C., Cuccia, E., Cavalli, F., Hjorth, J., Massabò, D., Nava, S., Udisti, R., Prati, P. 2014. Source apportionment of PM10 in the Western Mediterranean based on observations from a cruise ship. Atmos. Environ. 98, 510-518. 
Seinfeld, J.H., Pandis, S.N. Atmospheric chemistry and physics: from air pollution to climate change: John Wiley \& Sons, 2012.

Shen, G., Tao, S., Wei, S., Zhang, Y., Wang, R., Wang, B., Li, W., Shen, H., Huang, Y., Chen, Y. 2012. Emissions of parent, nitro, and oxygenated polycyclic aromatic hydrocarbons from residential wood combustion in rural China. Environ. Sci. Technol. 46, 8123-8130.

Shrivastava, M.K., Subramanian, R., Rogge, W.F., Robinson, A.L. 2007. Sources of organic aerosol: Positive matrix factorization of molecular marker data and comparison of results from different source apportionment models. Atmos. Environ. 41, 9353-9369.

Simoneit, B.R., Schauer, J.J., Nolte, C., Oros, D.R., Elias, V.O., Fraser, M., Rogge, W., Cass, G.R. 1999a. Levoglucosan, a tracer for cellulose in biomass burning and atmospheric particles. Atmos. Environ. 33, 173-182.

Simoneit, B.R.T., Schauer, J.J., Nolte, C.G., Oros, D.R., Elias, V.O., Fraser, M.P., Rogge, W.F., Cass, G.R. 1999b. Levoglucosan, a tracer for cellulose in biomass burning and atmospheric particles. Atmos. Environ. 33, 173-182.

Singh, D.K., Gupta, T. 2016. Role of transition metals with water soluble organic carbon in the formation of secondary organic aerosol and metallo-organics in PM 1 sampled during post monsoon and pre-winter time. J. Aerosol Sci. 94, 56-69.

Singh, D.K., Gupta, T. 2017. Role of ammonium ion and transition metals in the formation of secondary organic aerosol and metallo-organic complex within fog processed ambient deliquescent submicron particles collected in central part of Indo-Gangetic Plain. Chemosphere. 181, 725-737.

Singh, D.K., Kawamura, K., Yanase, A., Barrie, L.A. 2017. Distributions of Polycyclic Aromatic Hydrocarbons, Aromatic Ketones, Carboxylic Acids, and Trace Metals in Arctic Aerosols: Long-Range Atmospheric Transport, Photochemical Degradation/Production at Polar Sunrise. Environ. Sci. Technol. 51, 8992-9004.

Song, C.H., Carmichael, G.R. 1999. The aging process of naturally emitted aerosol (sea-salt and mineral aerosol) during long range transport. Atmos. Environ. 33, 2203-2218.

Srimuruganandam, B., Shiva Nagendra, S.M. 2012. Application of positive matrix factorization in characterization of PM10 and PM2.5 emission sources at urban roadside. Chemosphere. 88, 120-130.

Srivastava, D., Favez, O., Bonnaire, N., Lucarelli, F., Perraudin, E., Gros, V., Villenave, E., Albinet, A. In preparation. Speciation of organic fractions does matter for aerosol source apportionment. Part 2: Intensive campaign in the Paris area (France). Sci. Total Environ.

Srivastava, D., Goel, A., Agrawal, M. 2016. Particle Bound Metals at Major Intersections in an Urban Location and Source Identification Through Use of Metal Markers. Proceedings of the National Academy of Sciences, India Section A: Physical Sciences. 86, 209-220.

Sternbeck, J., Sjödin, Å., Andréasson, K. 2002. Metal emissions from road traffic and the influence of resuspension - results from two tunnel studies. Atmos. Environ. 36, 47354744.

Surratt, J.D., Gómez-González, Y., Chan, A.W.H., Vermeylen, R., Shahgholi, M., Kleindienst, T.E., Edney, E.O., Offenberg, J.H., Lewandowski, M., Jaoui, M., Maenhaut, W., Claeys, M., Flagan, R.C., Seinfeld, J.H. 2008. Organosulfate 
Formation in Biogenic Secondary Organic Aerosol. The Journal of Physical Chemistry A. $112,8345-8378$.

Tomaz, S., Jaffrezo, J.-L., Favez, O., Perraudin, E., Villenave, E., Albinet, A. 2017. Sources and atmospheric chemistry of oxy- and nitro-PAHs in the ambient air of Grenoble (France). Atmos. Environ. 161, 144-154.

Tomaz, S., Shahpoury, P., Jaffrezo, J.-L., Lammel, G., Perraudin, E., Villenave, E., Albinet, A. 2016. One-year study of polycyclic aromatic compounds at an urban site in Grenoble (France): Seasonal variations, gas/particle partitioning and cancer risk estimation. Sci. Total Environ. 565, 1071-1083.

Tong, H., Arangio, A.M., Lakey, P.S.J., Berkemeier, T., Liu, F., Kampf, C.J., Brune, W.H., Pöschl, U., Shiraiwa, M. 2016. Hydroxyl radicals from secondary organic aerosol decomposition in water. Atmos. Chem. Phys. 16, 1761-1771.

van Drooge, B.L., Grimalt, J.O. 2015. Particle size-resolved source apportionment of primary and secondary organic tracer compounds at urban and rural locations in Spain. Atmos. Chem. Phys. 15, 7735-7752.

Verma, S.K., Kawamura, K., Chen, J., Fu, P. 2017. Thirteen-years of observations on primary sugars and sugar alcohols over remote Chichijima Island in the western North Pacific. Atmos. Chem. Phys. 2017, 1-50.

Viana, M., Alastuey, A., Querol, X., Guerreiro, C., Vogt, M., Colette, A., Collet, S., Albinet, A., Fraboulet, I., Lacome, J.-M. 2015. Contribution of residential combustion to ambient air pollution and greenhouse gas emissions. ETC/ACM Technical Paper. 1.

Waked, A., Favez, O., Alleman, L.Y., Piot, C., Petit, J.E., Delaunay, T., Verlinden, E., Golly, B., Besombes, J.L., Jaffrezo, J.L., Leoz-Garziandia, E. 2014. Source apportionment of PM10 in a north-western Europe regional urban background site (Lens, France) using positive matrix factorization and including primary biogenic emissions. Atmos. Chem. Phys. 14, 3325-3346.

Walling, C. 1975. Fenton's reagent revisited. Acc. Chem. Res. 8, 125-131.

Wang, B., Knopf, D.A. 2011. Heterogeneous ice nucleation on particles composed of humic-like substances impacted by O3. Journal of Geophysical Research: Atmospheres. 116.

Wang, G., Chen, C., Li, J., Zhou, B., Xie, M., Hu, S., Kawamura, K., Chen, Y. 2011. Molecular composition and size distribution of sugars, sugar-alcohols and carboxylic acids in airborne particles during a severe urban haze event caused by wheat straw burning. Atmos. Environ. 45, 2473-2479.

Wang, Y., Hopke, P.K., Xia, X., Rattigan, O.V., Chalupa, D.C., Utell, M.J. 2012. Source apportionment of airborne particulate matter using inorganic and organic species as tracers. Atmos. Environ. 55, 525-532.

Yin, J., Allen, A., Harrison, R., Jennings, S., Wright, E., Fitzpatrick, M., Healy, T., Barry, E., Ceburnis, D., McCusker, D. 2005. Major component composition of urban PM 10 and PM 2.5 in Ireland. Atmospheric Research. 78, 149-165.

Yttri, K.E., Simpson, D., Stenström, K., Puxbaum, H., Svendby, T. 2011. Source apportionment of the carbonaceous aerosol in Norway \&ndash; quantitative estimates based on $14 \mathrm{C}$, thermal-optical and organic tracer analysis. Atmos. Chem. Phys. 11, 9375-9394. 
Zhang, Y., Sheesley, R.J., Schauer, J.J., Lewandowski, M., Jaoui, M., Offenberg, J.H., Kleindienst, T.E., Edney, E.O. 2009. Source apportionment of primary and secondary organic aerosols using positive matrix factorization (PMF) of molecular markers. Atmos. Environ. 43, 5567-5574.

Zhao, R., Mungall, E.L., Lee, A.K.Y., Aljawhary, D., Abbatt, J.P.D. 2014. Aqueous-phase photooxidation of levoglucosan - a mechanistic study using aerosol time-of-flight chemical ionization mass spectrometry (Aerosol ToF-CIMS). Atmos. Chem. Phys. 14, 9695-9706.

Zhou, S., Wenger, J.C. 2013a. Kinetics and products of the gas-phase reactions of acenaphthene with hydroxyl radicals, nitrate radicals and ozone. Atmos. Environ. 72, 97-104.

Zhou, S., Wenger, J.C. 2013b. Kinetics and products of the gas-phase reactions of acenaphthylene with hydroxyl radicals, nitrate radicals and ozone. Atmos. Environ. $75,103-112$.

Ziemann, P.J., Atkinson, R. 2012. Kinetics, products, and mechanisms of secondary organic aerosol formation. Chem. Soc. Rev. 41, 6582-605. 


\section{Figures}

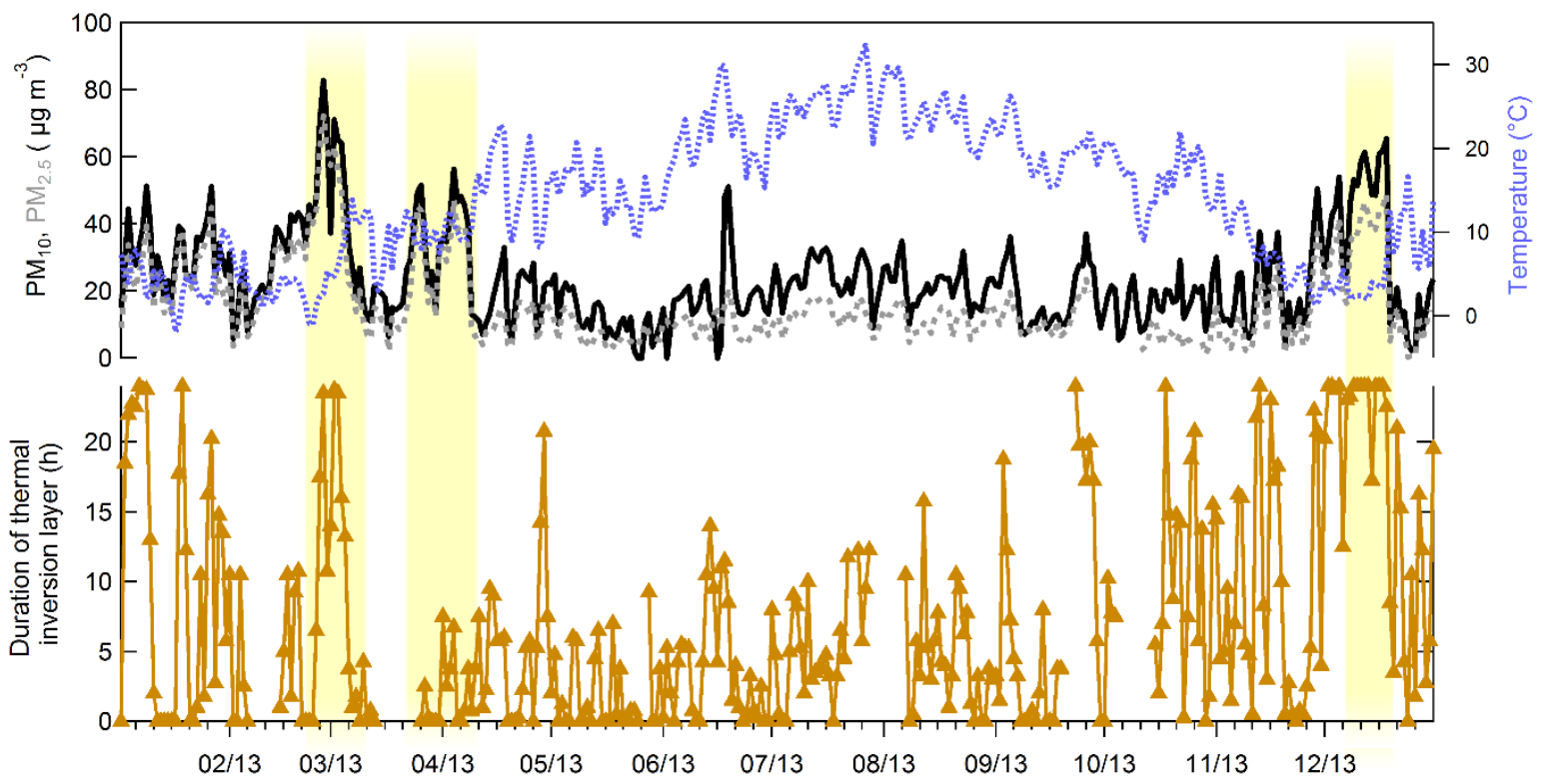

Figure 1. Temporal variation of $\mathrm{PM}_{10}$ and $\mathrm{PM}_{2.5}$ concentrations along with the temperature and duration of thermal inversion layers at Grenoble, Les Frênes (2013). 

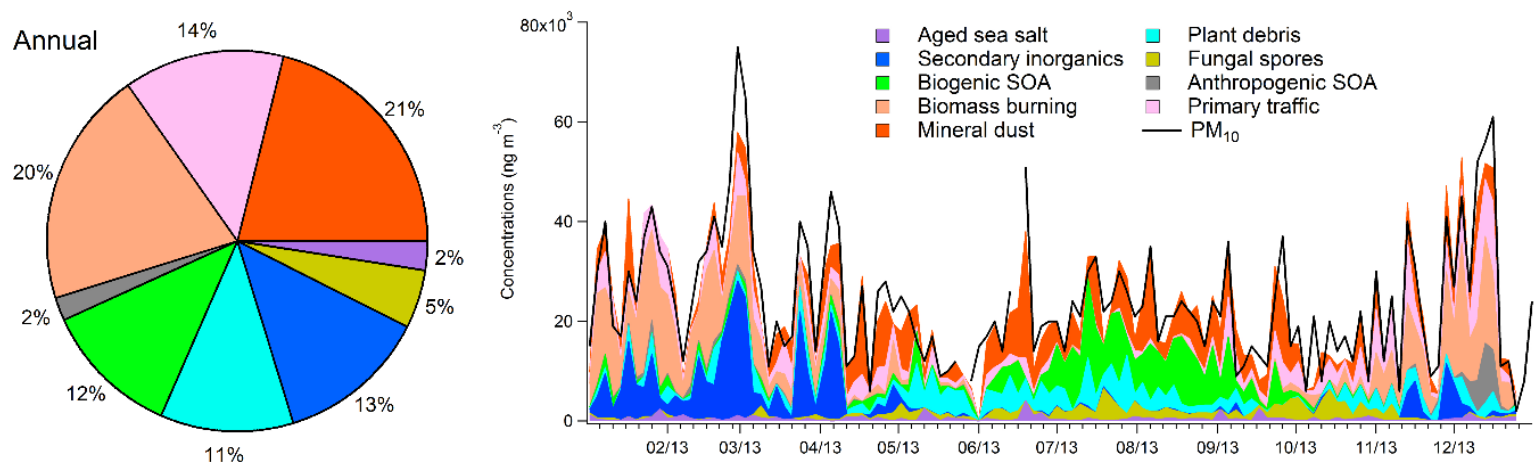

Figure 2. Annual average contributions (left) and temporal evolution (right) of the identified sources to $\mathrm{PM}_{10}$ mass concentrations in Grenoble, Les Frênes (2013). 


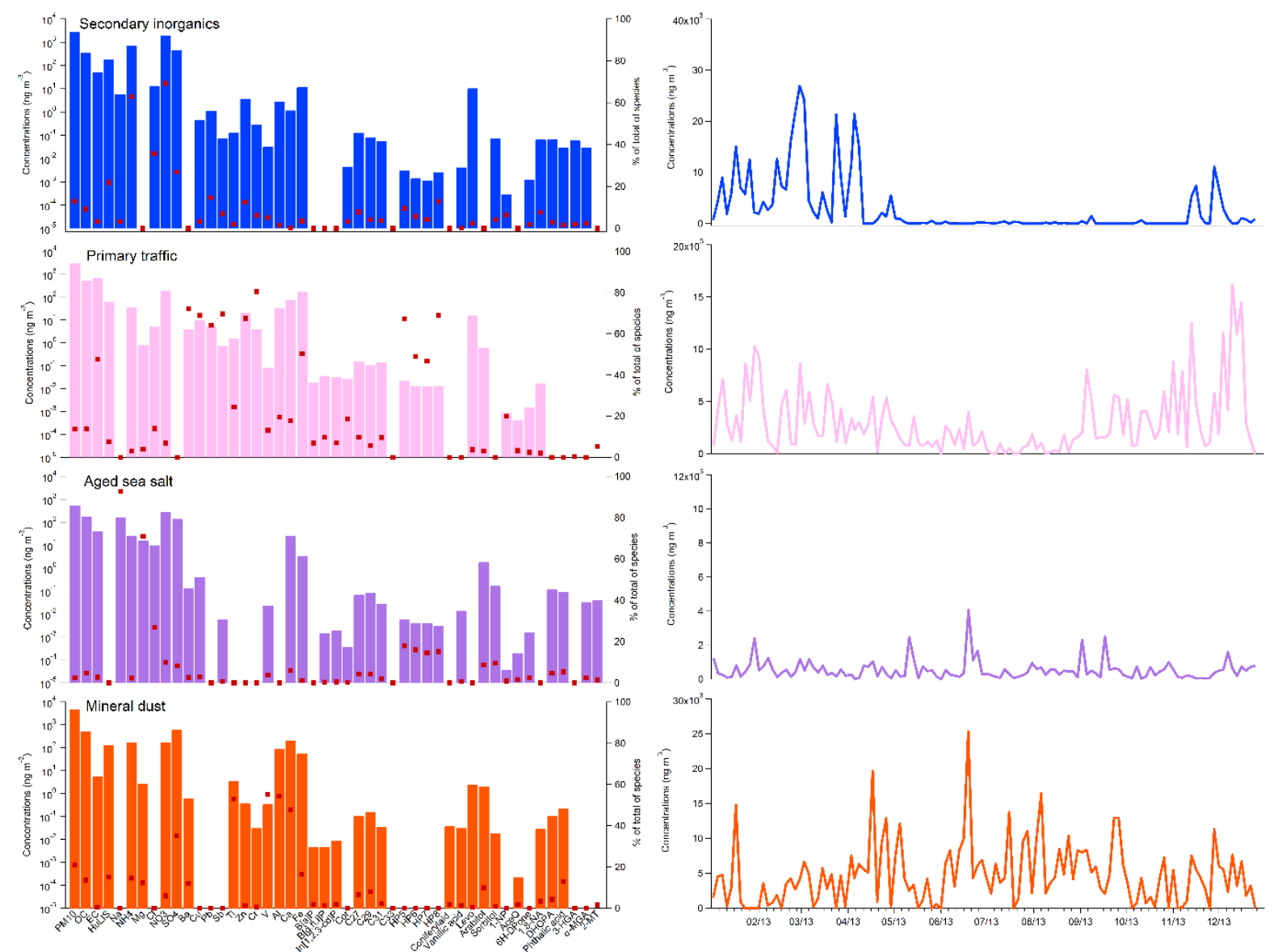

Figure 3. Source profiles and temporal evolution of secondary inorganic, primary traffic, aged sea salt and mineral dust factors identified at Grenoble, Les Frênes (2013). 

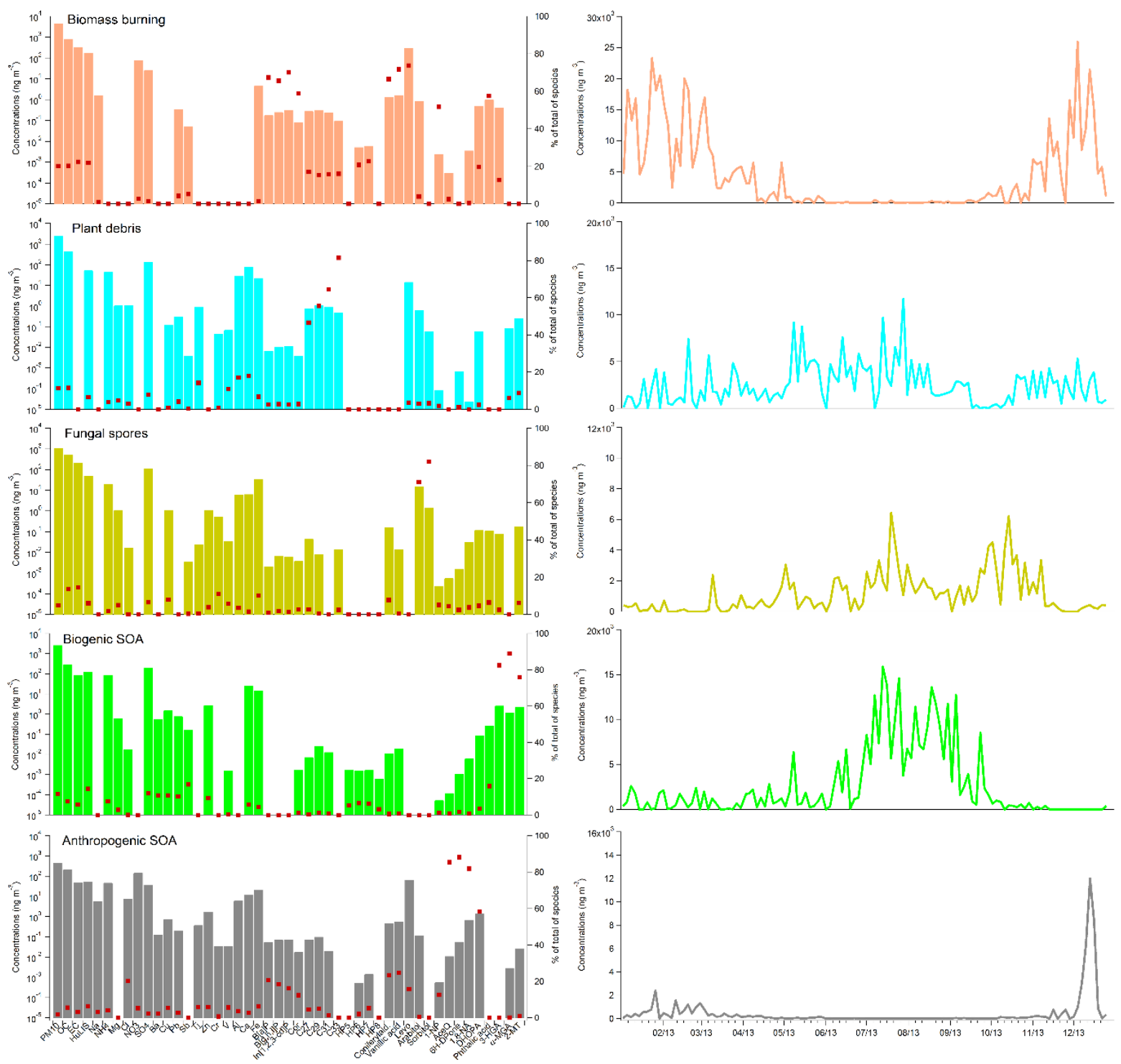

Figure 4. Source profiles and temporal evolution of plant debris, fungal spores, biogenic SOA and anthropogenic SOA identified at Grenoble, Les Frênes (2013). 


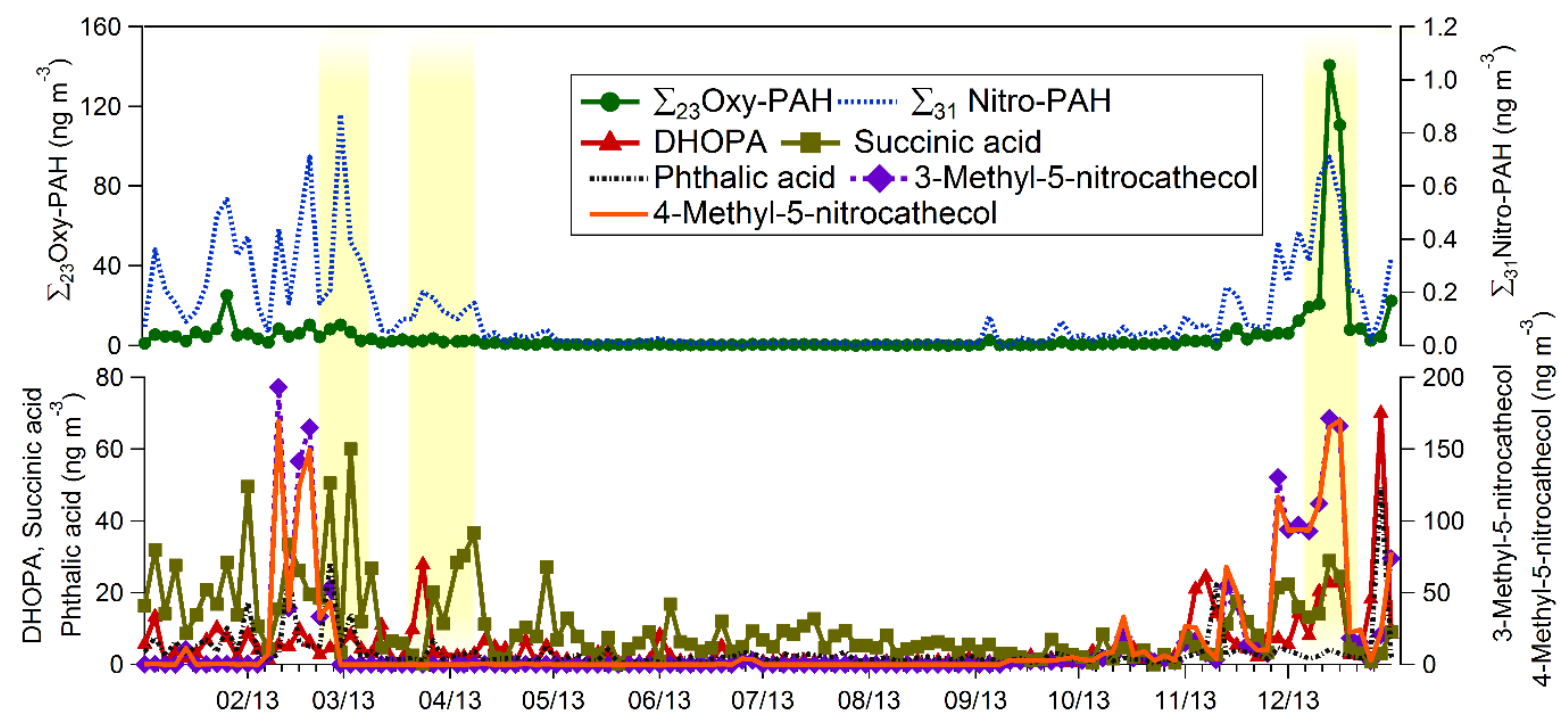

Figure 5. Temporal variation of the concentrations of $\Sigma_{23} \mathrm{Oxy}-\mathrm{PAHs}, \Sigma_{31} \mathrm{Nitro}-\mathrm{PAHs}$, DHOPA, methyl-nitrocatechols, succinic and phthalic acids observed at Grenoble, Les Frênes (2013). 


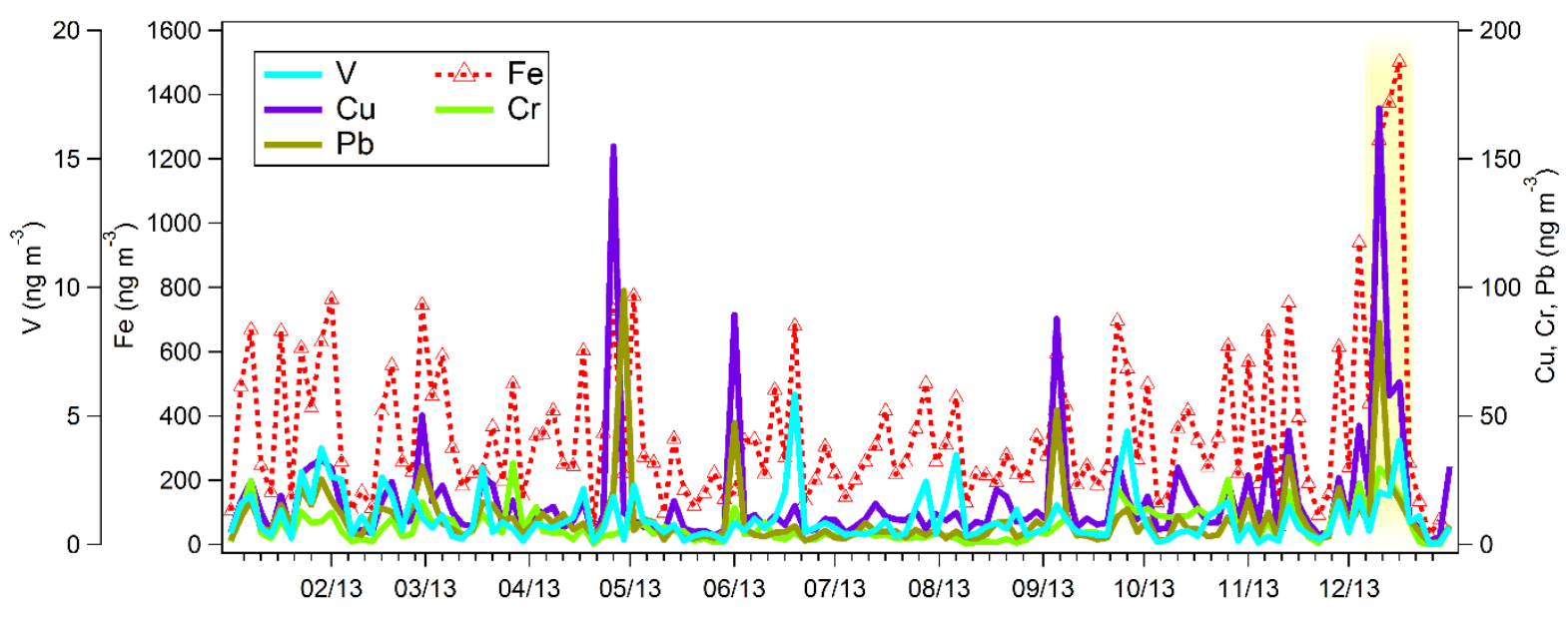

Figure 6. Temporal variation of selected metal concentrations ( $\mathrm{Fe}, \mathrm{Cu}, \mathrm{Cr}, \mathrm{Pb}$, and $\mathrm{V}$ ) observed at Grenoble, Les Frênes (2013). 


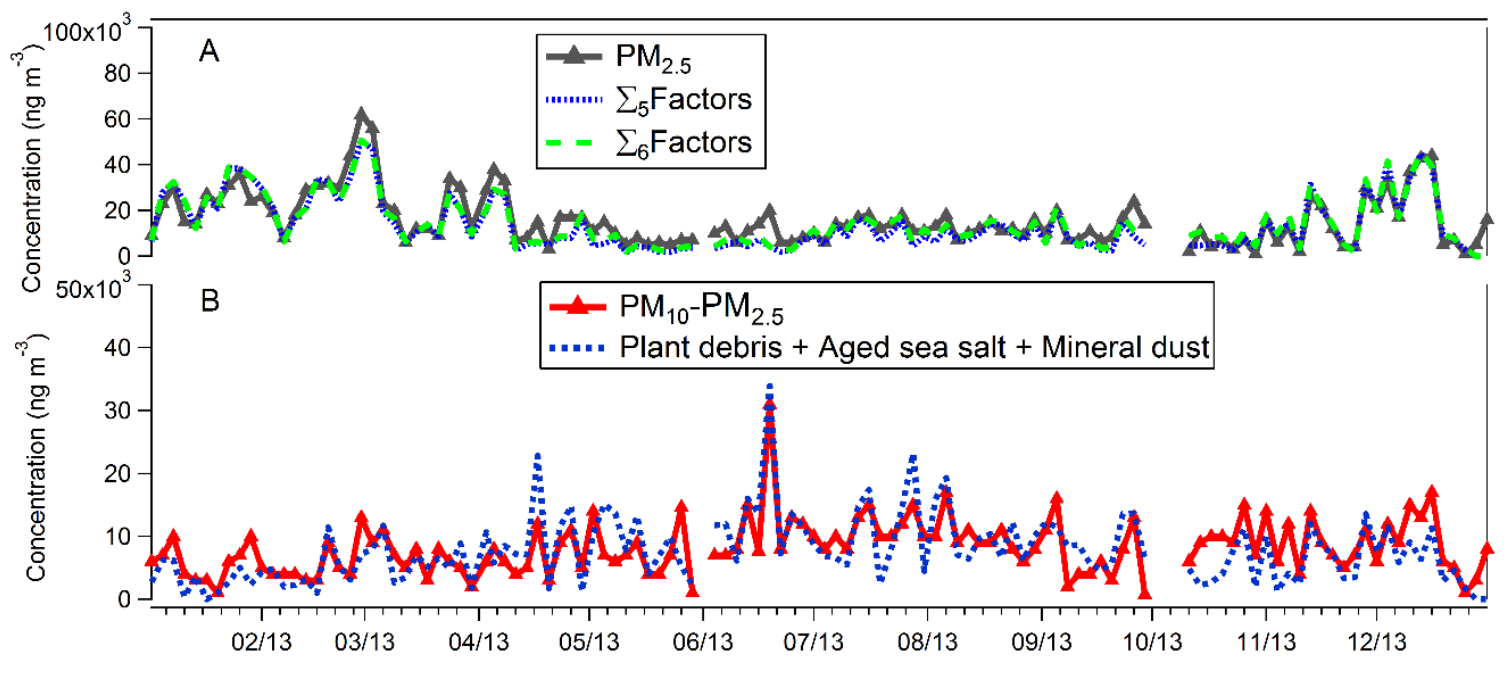

Figure 7. Tentative reconstruction of fine $\left(\mathrm{PM}_{2.5}\right)(\mathrm{A})$ and coarse $\left(\mathrm{PM}_{10}-\mathrm{PM}_{2.5}\right)(\mathrm{B})$ aerosol fractions observed at Grenoble, Les Frênes (2013) using identified PM sources by PMF model. $\Sigma_{5}$ Factors $=$ Primary traffic + Secondary inorganic + Biomass burning + Anthropogenic SOA+ Biogenic SOA.; $\Sigma_{6}$ Factors = Primary traffic+ Secondary inorganic + Biomass burning + Anthropogenic SOA + Biogenic SOA + Fungal spores. 

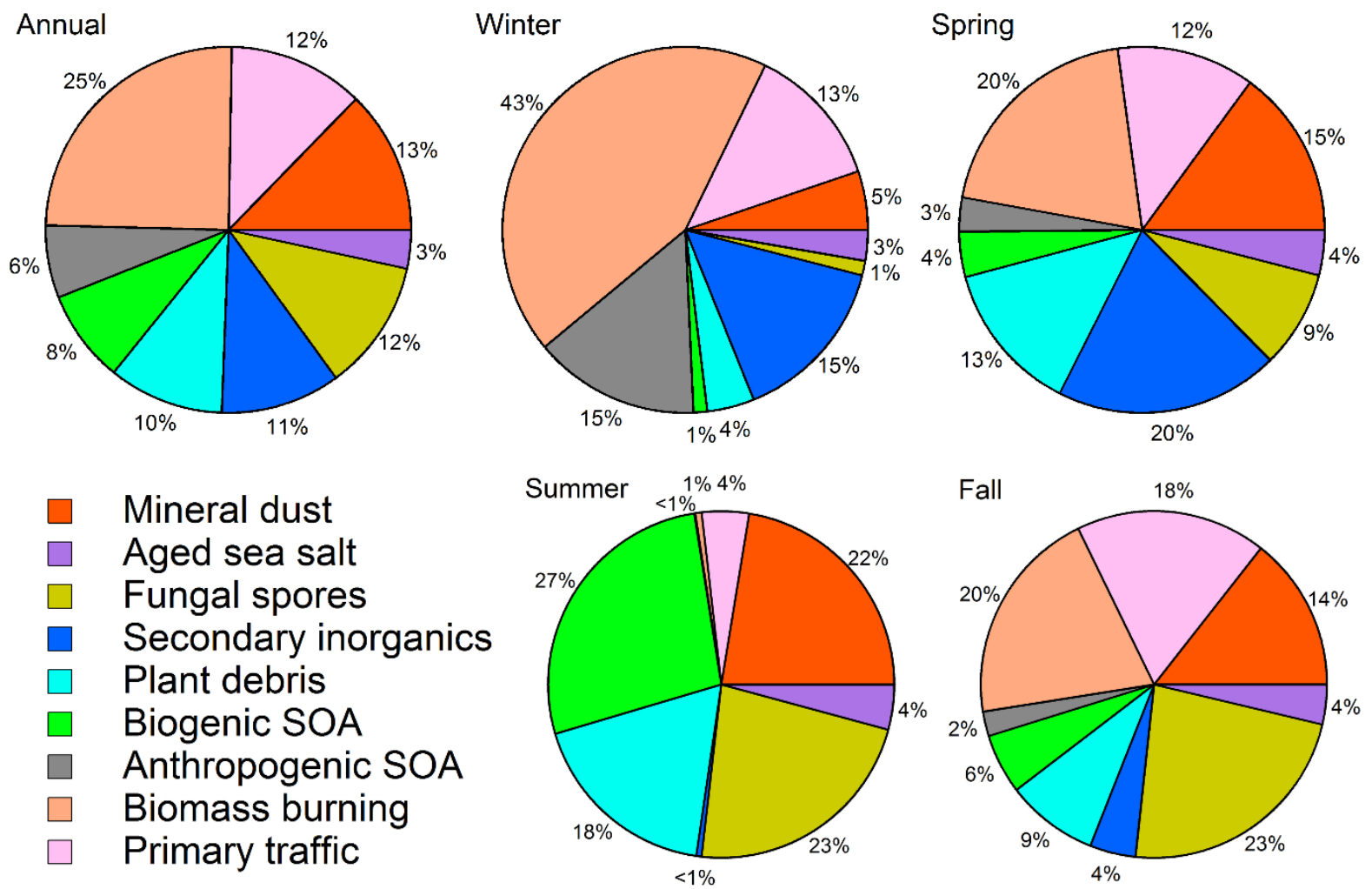

Figure 8. Annual and seasonal contributions of the identified sources to OC concentrations at Grenoble, Les Frênes (2013). 

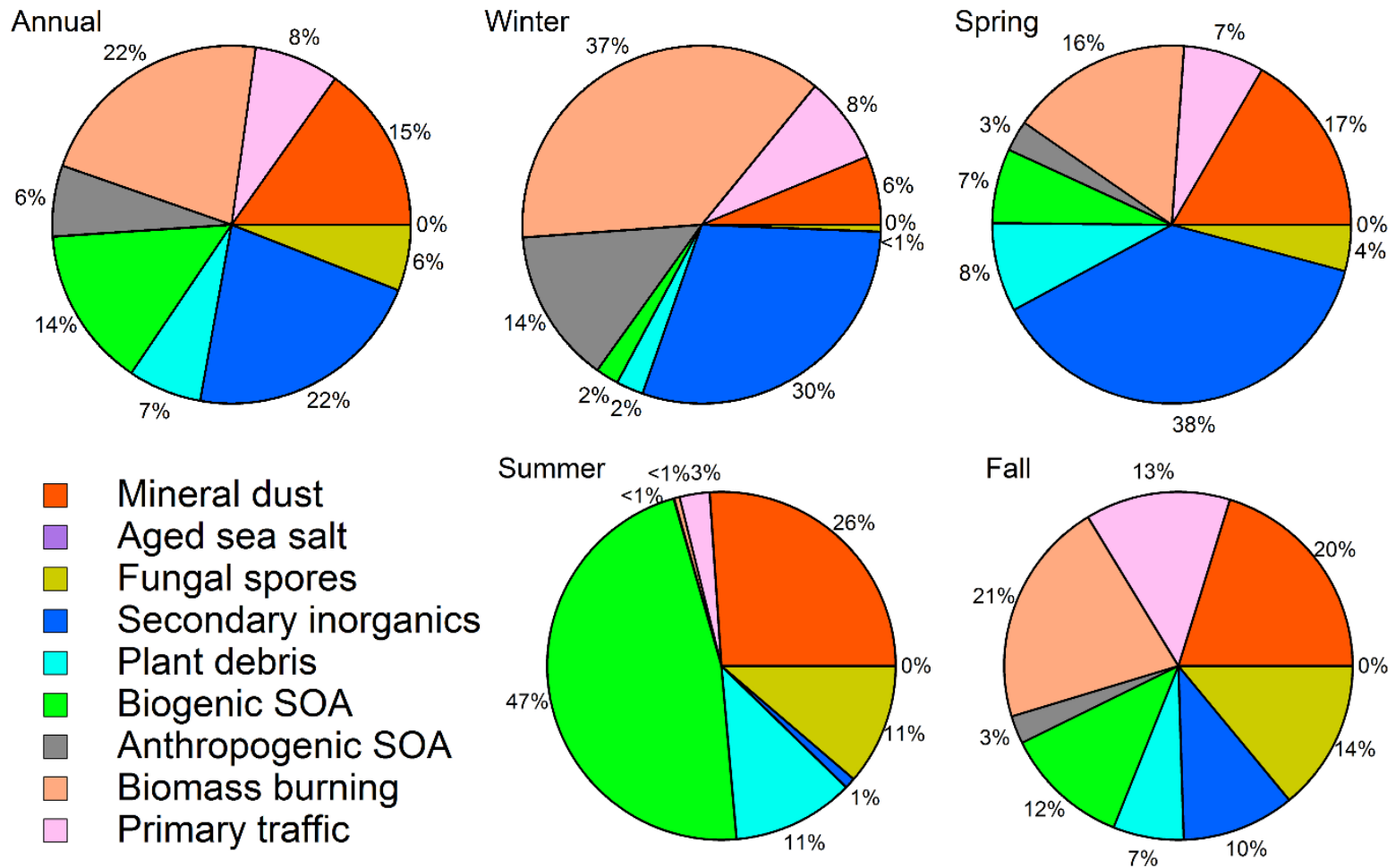

Figure 9. Annual and seasonal contributions of the identified sources to HuLiS concentrations at Grenoble, Les Frênes (2013). 